\title{
Modelling smart energy systems in tropical regions
}

Dominkovic, D. F.; Dobravec, V. ; Jiang, Y.; Nielsen, P. S.; Krajai, G.

\section{Published in:}

\section{Energy}

Link to article, DOI:

10.1016/j.energy.2018.05.007

Publication date:

2018

Document Version

Peer reviewed version

Link back to DTU Orbit

Citation (APA):

Dominkovic, D. F., Dobravec, V., Jiang, Y., Nielsen, P. S., \& Krajai, G. (2018). Modelling smart energy systems in tropical regions. Energy, 155, 592-609. https://doi.org/10.1016/j.energy.2018.05.007

\section{General rights}

Copyright and moral rights for the publications made accessible in the public portal are retained by the authors and/or other copyright owners and it is a condition of accessing publications that users recognise and abide by the legal requirements associated with these rights.

- Users may download and print one copy of any publication from the public portal for the purpose of private study or research.

- You may not further distribute the material or use it for any profit-making activity or commercial gain

- You may freely distribute the URL identifying the publication in the public portal

If you believe that this document breaches copyright please contact us providing details, and we will remove access to the work immediately and investigate your claim. 


\section{Accepted Manuscript}

Modelling smart energy systems in tropical regions

D.F. Dominković, V. Dobravec, Y. Jiang, P.S. Nielsen, G. Krajačić

PII: S0360-5442(18)30826-0

DOI: $\quad$ 10.1016/j.energy.2018.05.007

Reference: EGY 12840

To appear in: Energy

Received Date: 1 January 2018

Revised Date: 23 March 2018

Accepted Date: 1 May 2018

Please cite this article as: Dominković DF, Dobravec V, Jiang Y, Nielsen PS, Krajačić G, Modelling smart energy systems in tropical regions, Energy (2018), doi: 10.1016/j.energy.2018.05.007.

This is a PDF file of an unedited manuscript that has been accepted for publication. As a service to our customers we are providing this early version of the manuscript. The manuscript will undergo copyediting, typesetting, and review of the resulting proof before it is published in its final form. Please note that during the production process errors may be discovered which could affect the content, and all legal disclaimers that apply to the journal pertain. 


\title{
Modelling smart energy systems in tropical regions
}

\author{
D. F. Dominković* \\ Department of Energy Conversion and Storage \\ Technical University of Denmark (DTU), Frederiksborgvej 399, Roskilde, Denmark \\ e-mail:dodo@dtu.dk \\ V. Dobravec \\ Faculty of Mechanical Engineering and Naval Architecture \\ University of Zagreb, Zagreb, Croatia \\ viktorija.dobravec@fsb.hr \\ Y. Jiang \\ Environmental Economics and Natural Resources Group, \\ Wageningen University \& Research, \\ Hollandseweg 1, 6706 KN, Wageningen, The Netherlands \\ yu.jiang@wur.nl \\ P. S. Nielsen \\ Department of Management Engineering \\ Technical University of Denmark (DTU) Produktionstorvet 426, Lyngby, Denmark \\ pernn@dtu.dk \\ G. Krajačić \\ Faculty of Mechanical Engineering and Naval Architecture \\ University of Zagreb, Zagreb, Croatia \\ goran.krajacic@fsb.hr
}

(6)

6

\begin{abstract}
A large majority of energy systems models of smart urban energy systems are modelling moderate climate with seasonal variations, such as the European ones. The climate in the tropical region is dominated by very high stable temperatures and high humidity and lacks the moderate climate's seasonality. Furthermore, the smart energy system models tend to focus on $\mathrm{CO}_{2}$ emissions only and lack integrated air pollution modelling of other air pollutants. In this study, an integrated urban energy system for a tropical climate was modelled, including modelling the interactions between power, cooling, gas, mobility and water desalination sectors. Five different large scale storages were modelled, too. The developed linear optimization model further included endogenous decisions about the share of district versus
\end{abstract}


individual cooling, implementation of energy efficiency solutions and implementation of demand response measures in buildings and industry. Six scenarios for the year 2030 were developed in order to present a stepwise increase in energy system integration in a transition to a smart urban energy system in Singapore. The economically best performing scenario had $48 \%$ lower socio-economic costs, $68 \%$ lower $\mathrm{CO}_{2} \mathrm{e}$ emissions, $15 \%$ higher PM emissions and $2 \%$ larger primary energy consumption compared to a business-as-usual case.

Key words: air pollution; energy storage modelling; district cooling; smart cities; smart energy system; tropical climate

\section{Nomenclature}

$a b s_{D C}$ Cold production for district cooling (DC) from single phase absorption units, $\mathrm{MWh}_{\mathrm{c}}$

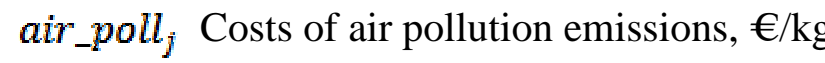

air_poll inten,j $_{j}$ Air pollution intensity of a certain technology or energy within the system boundaries, $\mathrm{kg} / \mathrm{MWh}$

$B_{y}$ Binary variable ( 0 or 1 ) used for modelling the choice of the refurbishment scenario

bio_cap Maximum allowed biomass consumption in the modelled system, MWh

chiller $_{D C}$ Production of cold in DC from centralized electric chillers, MWh

$C O P_{D C_{\text {chiller }}}$ Coefficient of performance of chillers in DC

chiller $_{\text {individual }}$ Production of cold from individual electric chillers, MWh

cool $_{\text {en,ef }}$ Reduced cooling energy demand due to the increased energy efficiency, MWh

$\operatorname{cool}_{\text {demand,total }}$ Total cooling demand, MWh

$C O P_{\text {individual }}$ Coefficient of performance of individual chillers

$C O P_{a b s}$ Coefficient of performance of absorbers

CO2_cap Maximum amount of emissions allowed in the system, ton

CO2_inten $_{j} \mathrm{CO}_{2}$ intensity of a certain technology or energy within the system boundaries, ton/MWh

$\mathrm{CO}_{\text {inten }_{k}} \mathrm{CO}_{2}$ intensity of a certain technology or energy coming in or out of the system boundaries, ton/MWh

$\mathrm{CO}_{j}$ Costs of $\mathrm{CO}_{2}$ emissions, $€ /$ ton 
69

70

71

72

73

74

75

$D C_{\text {demand }}$ DC demand, MWh

dis_rate $_{i}$ Discount rate of the technology $i, \%$

el_dem Electricity demand, MWh

ela Elasticity of willingness to pay with respect to income

ele $e_{\text {transport }}$ Electricity demand for electrified part of the transport sector, MWh

fix_o\& $M_{i}$ Fixed operating and maintenance costs of energy plants, €/MW

flex Reduced electricity demand due to the load shifted in industry or buildings sector, MWh

flex $_{c h}$ Additional demand for electricity due to the shifted load demand, MWh

fuel $_{j}$ Fuel cost of specific energy type, $€ / \mathrm{MWh}_{\text {fuel }}$

gas_dem Gas demand, MWh

gas_imp $p_{k}$ Price of import or export of gas in a specific hour, €/MWh

gas $_{\text {synthesis }}$ Synthetic natural gas production from syngas using gas synthesis, MWh

geothermal $_{D C}$ Cold production for DC from geothermal waste heat, MWh

heat_level $l_{r}$ Heating energy content stored in the energy storage, MWh

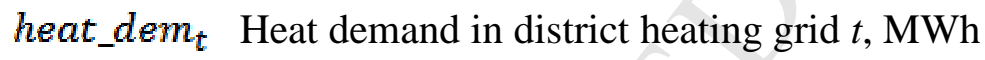

$i \quad$ Energy technology index

ind_cool demand Individual cooling demand, MWh

inv $v_{i}$ Total investment in technology $i, €$

$i n v_{e n_{e}, f_{i}, y}$ Investment cost of a certain building energy efficiency scenario, $€$

$i$ Energy technologies that consume fuels and have emissions

lev_inv $v_{i}$ Levelized cost of investment over the energy plant lifetime, $€ / \mathrm{MW}$

lifetime $_{i}$ Lifetime of the technology $i$, years

$M E C_{\text {Sing }}$ Marginal external cost of air pollution in Singapore, $€ /$ ton

$M E C_{U K}$ Marginal external cost in the United Kingdom, €/ton

methanol Methanol production via synthesis from syngas, MWh

petr_dem Gasoline demand, MWh 
petr_imp $p_{k}$ Price of import of gasoline in a specific hour, $€ / \mathrm{MWh}$

RO Fresh water production from sea water desalination using reverse osmosis, $\mathrm{m}^{3}$

SOEC Hourly production of syngas from solid-oxide electrolysers, MWh

SOFC Hourly production of electricity from solid-oxide fuel cells, MWh

$t$ hour, h

var_O\&M$\quad$ Variable operating and maintenance costs of energy plants, $€ / M W h$

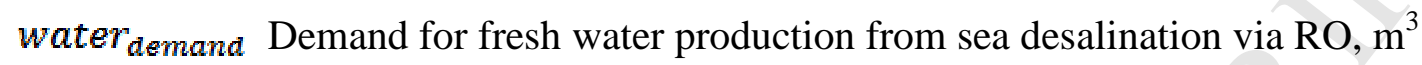

$x_{i}$ Capacity variables of energy plants and gas grid, MW

$x_{j}$ Generation capacities of energy plants (8,760 variables for each energy plant, representing the generation in each hour during the one year), MWh

$x_{j, E L}$ Hourly generation of technologies which generate electricity, MWh

$x_{j, E L, b i o m a s s}$ Hourly generation of technologies which generate electricity and are driven by biomass, MWh

$x_{j, E L, g a s}$ Hourly generation of technologies which generate electricity and are driven by gas, $\mathrm{MWh}$

$x_{j, E L_{\text {other }}}$ Hourly generation of technologies which generate electricity and are driven by other fuel types, or are not fuel-driven (Photovoltaics (PVs) and wind turbines), MWh

$x_{j, \text { battery,storage }}$ Hourly charge of vehicles battery storage, MWh

$x_{j, b a t t e r y, s t o r a g e \_d i s}$ Hourly discharge of electricity of vehicles battery storage, MWh

$x_{j, \text { battery,storage_grid_dis,r }}$ Hourly discharge of electricity of vehicles battery storage to the power grid (vehicle-to-grid (V2G)), MWh

$x_{j, g r i d_{\text {battery }}, \text { storage }}$ Hourly charge of electricity grid battery storage, MWh

$x_{j, g r i d \_b a t t e r y, s t o r a g e \_d i s}$ Hourly discharge of electricity grid battery storage, MWh

$x_{j, \text { heat,storage_ch,t }}$ Hourly charge of heat to the heat storage operated in the DH system $t$, MWh

$x_{j, \text { heat,storage_dis,t }}$ Hourly discharge of heat from the heat storage operated in the DH system $t, \mathrm{MWh}$

$x_{j, a n \_ \text {dig }}$ Generation of gas after $\mathrm{CO}_{2}$ removal in anaerobic digester, MWh 
$x_{j, \text { wasteheat, } l}$ Heat generation needed for absorption chillers; from gas, biomass, waste CHPs, solar thermal or waste heat from data centres, MWh

$x_{k} \quad$ Import or export across the system boundaries of different types of energy $(8,760$ variables per one type of energy, representing the flow in each hour during the one year), MWh

$128 y$ Chosen refurbishment scenario (out of several predefined ones), integer value

$Y_{\text {Sing }}$ Gross national income per capita at purchasing power parity in Singapore, $\$$

$Y_{U K}$ Gross national income per capita at purchasing power parity in the United Kingdom, \$

$\eta_{j}$ Efficiency of technology, $\mathrm{MWh}_{\text {energy }} / \mathrm{MWh}_{\text {fuel }}$

\section{Introduction}

133 Climate change has become one of the most important topics in political discussions among nations and cities around the world in recent years. Energy production and consumption are responsible for two-thirds of the world's greenhouse gas (GHG) emissions, making the energy sector one of the main contributors to the man-made climate change [1]. In order to tackle that problem, 195 countries worldwide signed the Paris agreement in 2015 [2]. The countries committed themselves to increase its efforts to cut $\mathrm{CO}_{2} \mathrm{e}$ emissions with the aim of keeping the projected growth in global average temperature below $2^{\circ} \mathrm{C}$. An important part of those efforts is changing local and national energy systems from using fossil fuels towards using renewable energy sources (RES). Coastal cities are especially vulnerable to the climate change due to the sea level rise potential, stronger storms and other unexpected weather events.

Cities will be among the major contributors in this transition process. Today, $54 \%$ of the world's population lives in cities and the United Nations forecasts that the share is expected to continuously grow, resulting in $66 \%$ of the world's population being urban in 2050 [3]. Cities are also facing the challenge of increasing energy consumption per capita, as urban energy use in the last 25 years has grown more than the urbanisation rate [4]. Cities can therefore easily become hotspots of air pollution, as they concentrate people, traffic, construction activity and energy use [5]. The World Health Organisation (WHO) states that more than $80 \%$ of the global urban population is exposed to air quality levels that are below WHO recommendations [6]. Particularly interesting in this context are cities in tropical climates. While heating demand accounts for a predominant part of the total energy consumption in moderate and cold climates, tropical climates are experiencing an ever growing cooling demand, as they are dominated by humid air and high temperatures throughout the year [7]. It is therefore important to analyse future energy systems in cities located in tropical climates, with a special emphasis on residential cooling.

158 Cooling systems have been the main focus in many research papers. Bruelisauer et al. [7] 159 analysed thermal properties of heat sinks and their effect on the performance of air- 
160 conditioning systems and showed that the temperature lift is particularly important for the performance of the overall cooling system in tropical climates like Singapore. With a focus on district cooling systems, the authors in [8] have emphasised how most of such systems are oversized, which leads to inefficient operation and overestimated investment costs. They developed a novel stochastic model for simulating cooling loads and applied it to a residential district in Wuhan, China. They found that oversimplified occupant behaviour assumptions caused overestimations of the peak and total cooling load. However, their model did not include system impacts of cooling loads on the whole energy system. Furthermore, Hoyo Arce et al. [9] developed a method for fast modelling of district heating and cooling networks, while a dynamic thermo-hydraulic model for district cooling networks was presented in [10]. The latter can be used for answering different economic and energy efficiency-related questions in design and operation of district cooling networks. However, both [9] and [10] focused solely on the district cooling sector and not on the overall energy system. B.W Ang et al. [11] had the tropical and sub-tropical climate conditions as the main focus when they analysed how outdoor temperature increases affected electricity consumption in Singapore and Hong Kong. Their results showed that an average increase of $1{ }^{\circ} \mathrm{C}$ could cause a 3\%-5\% growth in total annual electricity consumption, due to increase in space cooling demand. Finally, Werner [12] provided an overview of the current situation of district heating and cooling systems in the world. His analysis revealed that around $67 \%$ of the global annual cooling demand came from the Middle East, where the average temperatures were much higher than in, for example, Europe or the United States. Moreover, he emphasised that future possibilities for larger-scale implementation of district cooling were promising; however, strong efforts were needed in order to realise them.

183 District cooling systems are especially beneficial when they are integrated with the distributed energy generation technologies, such as wind turbines or solar panels. Synergies between various energy generation and storage technologies with district heating or cooling networks can result in lower carbon emission, higher energy efficiency and reliability. While there are many studies focusing on the system integration in the regions where heating or both space heating and cooling are needed, the application and performance of district cooling integration for cooling dominated regions is still rarely investigated. One example of such integration for a small-scale area, namely a campus in Hong Kong has been carried out in [13]. Designed distributed energy system showed reduction in primary energy consumption and economic benefits due to the low operational costs. In [14], Hughes et al. investigated economic feasibility of combining desalination system with district cooling plants by utilizing waste heat recovery, demonstrating that the combination of the technologies is more cost effective than using the technologies independently. Moreover, utilization of intermittent renewable energy sources in district energy systems in hot-climates with a strong focus on exergetic analysis of ice storage was examined in [15]. Modelled scenarios included electricity generation, storage technologies and district cooling systems. However, the other parts of the energy system like transport sector and water desalination systems were not considered, 
In order to respond to increasing variability and uncertainty of demand due to the growing penetration of variable renewable energy technologies, future energy systems require high degree of system flexibility. Flexibility can be provided by a variety of options such as interventions in system operation, markets, load, network, storages or through flexible generation [16]. A significant aspect of load interventions is demand response management (DSM). DSM has been especially well researched for operation of flexible consumption in residential sector where it can be used for various appliances, namely washing machines, dryers, dishwashers and electric hot water heaters [17]. A comprehensive review of DSM in variety of other sectors was given in [18]. The review showed considerable potential for flexibility in industry, commercial as well as households sector. However, the potential of DSM so far has not been modelled as a part of the overall energy system design.

Another important issue when modelling future energy systems is the inclusion of different externalities in the total costs of the system. These are mainly environmental costs and human-health related costs. When including the externalities from the urban energy system into the energy system modelling, most of the previous studies only took the greenhouse gas emissions into account. The air pollution was usually ignored [19]. Only a few studies considered the air pollution control aspects [20]. However, these studies used air pollution control element as model constraints and did not provide information about the external costs of the air pollution. Another example is the study in [21], where Zvingilaite investigated human-health related externalities in an energy system modelling on the case of the Danish heat and power sectors. The main focus of the study was the energy production-related air pollution and the results showed that it was cheaper for the society to include externalities in the initial process of energy system planning than to pay for the resulting damages later. Thus, there is a research gap in terms of air pollution integrated holistic modelling in urban energy systems. In this study, the issue of air pollution was tackled by inclusion of the internalized external costs of the air pollution (NOx, SOx and PM emissions) in the total socio-economic cost.

Nevertheless, this paper addresses the interplay between implementing energy efficiency measures in buildings, district energy share in the total thermal energy demand and renewable energy supply. The latter interplay was assessed in great detail in [22]; however, the assessment was carried out for European countries, dominated by distinct seasons throughout the year. The interplay being assessed in this paper focuses on the tropical climates, dominated by lack of seasonality in demand, with majority of thermal energy demand being in the form of cooling demand.

The presented literature review shows that there is a lack of systematic research on cooling integration into energy systems in hot and humid climates. Smart energy systems [23], including smart district heating systems, have been the topic of research for many different use cases, whereas, there is a lack of research on the potential of district cooling integration with other energy sectors constituting smart energy system. Furthermore, concerning the best of knowledge of the authors, there is no research dealing with the integration of district cooling into smart energy systems and future smart energy cities in tropical regions. 
242 In order to improve the state-of-the art of the energy planning in the tropical climates, this

243 paper brings the following novelties:

244

245

246

247

248

249

250

251

252

253

254

255

256

257

258

259

260

261

262

263

264

265

266

267

268

269

270

271

272

273

274

275

276

277

278

279

280

- Integrated, holistic urban energy modelling has been applied to the tropical climate, dominated by the lack of distinct seasonality, having steady cooling demand, as well as solar insolation throughout the year. The integrated urban energy systems in this paper included power, cooling, gas, mobility and water desalination sectors.

- Air pollution has been endogenously modelled and different sources of air pollution have been tackled. The air pollution costs were internalized in the overall socio-economic costs.

- The interplay between energy supply, district (cooling) energy supply and energy efficiency has been endogenously modelled, meaning that neither of the shares was predefined by a modeller.

- Flexible demand of industry and buildings has been also endogenously modelled, having as a consequence the possibility that the model result selects the optimal mix of solutions in the complex urban environment.

- A comparison between the energy systems of a city seeking for the self-sustainability and when it also utilizes the energy from its surroundings has been carried out.

Thus, the aim of this paper is to assess whether the district cooling (DC) adoption in hot and humid climates is socio-economically feasible on the system scale and whether it can serve as an integration point for intermittent renewable energy sources. Moreover, the aim of the developed model is to find the optimal mix between the renewable energy supply, district cooling and building energy efficiency. Finally, the air pollution and external costs those emissions are imposing on the society have been calculated and put into the $\mathrm{CO}_{2}$ emissions agenda perspective.

This paper is organized as follows, in the Methods section, a flow chart of the model is presented in order to make it clearer what is the model being used here capable of modelling. Moreover, the most important equations of the optimization model are presented here, while the complete optimization model is presented in Appendix B. The case study that was used to represent a hot climate is presented in the Case study and scenario development section. Further section presents the most important results, showing the interplay between different energy sectors, primary energy savings, air pollution impact and GHG emissions of different scenarios. The paper ends with a discussion of the results, outlook of the future research and main conclusions of this paper.

\section{Methods}

The smart energy system was modelled taking electricity, cooling, water desalination, gas and mobility sectors into account. A linear mixed-integer optimization model was developed using Gurobi solver and Matlab interface. Integer variables were constrained to binary ones only.

The optimization model used in this paper is a significantly expanded version of the model that was previously developed in [24], and expanded in [25]. The model was improved by 
281 adding endogenous decisions on the share of DC versus individual cooling, selecting energy 282 efficiency strategy in buildings and implementing DSM in industry and households. It was 283 further improved by adding $\mathrm{N}_{2} \mathrm{O}$ and $\mathrm{CH}_{4}$ gases to the $\mathrm{CO}_{2}$, in order to better represent GHG 284 emissions, and modelling the air pollution. Throughout this paper, $\mathrm{N}_{2} \mathrm{O}, \mathrm{CH}_{4}$ and $\mathrm{CO}_{2}$ 285 emissions are jointly reported as $\mathrm{CO}_{2 \mathrm{e}}$ emissions. The flow chart of the optimization model 286 can be seen in Figure 1. This section follows with the explanation of the most important 287 equations of the optimization model, while the representation of all the equations of the 288 optimization model can be found in Appendix B. 
- Hourly transport demand
- Hourly electricity demand
- Hourly cooling demand
- Yearly desalinated water demand

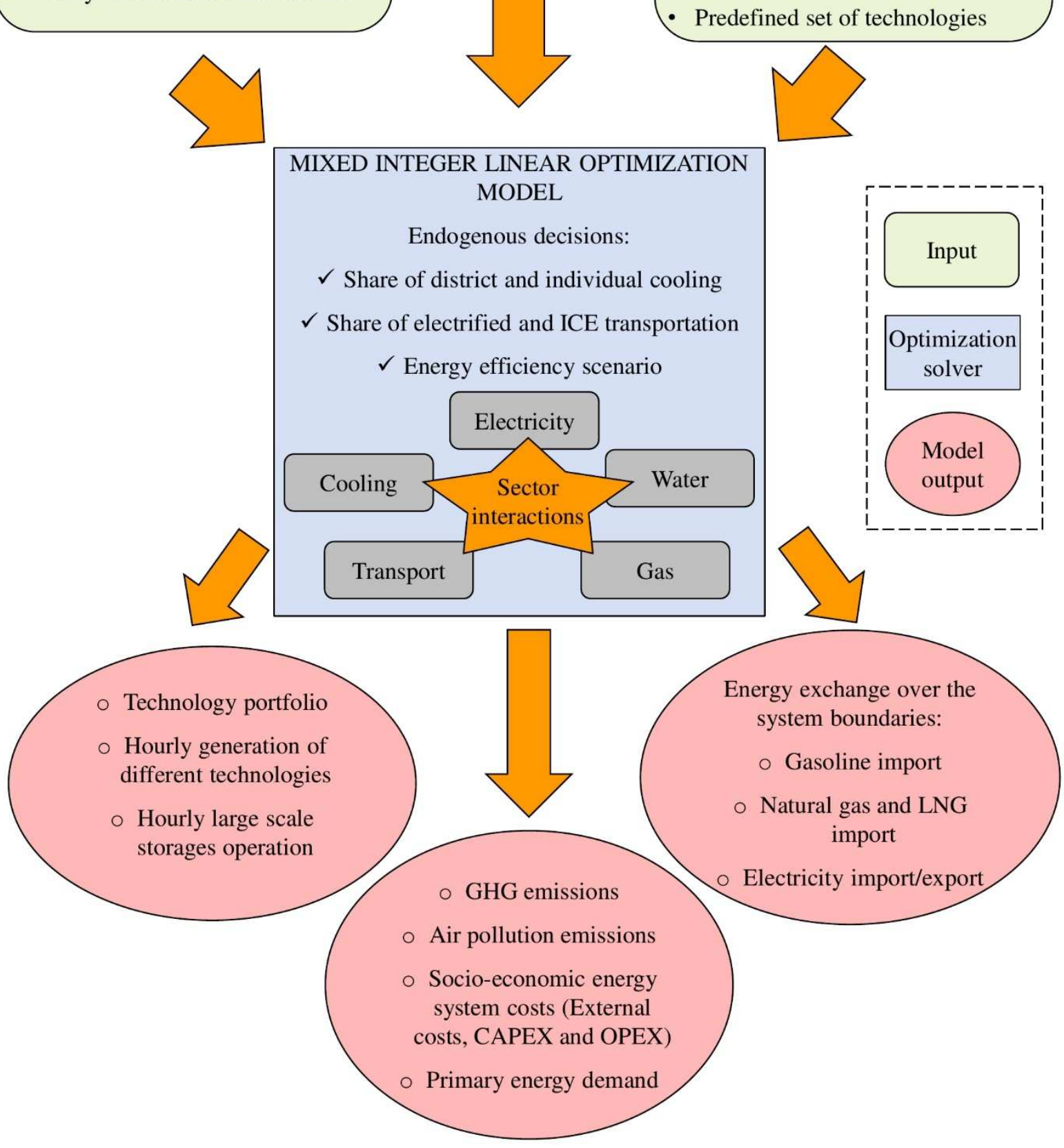

290 Figure 1. A flow chart of the optimization model used for the energy system planning 


\section{Objective function and variables}

The goal of the optimization was to minimize the total socio-economic costs, as shown in eq. ( 1 ). The total socio-economic costs included levelized costs of investment over the lifetime of the energy plant, storages, smart controls for load shifting and energy refurbishment of buildings, fixed and variable operating and maintenance $(\mathrm{O} \& \mathrm{M})$ costs, fuel costs, $\mathrm{CO}_{2}$ costs, costs of other greenhouse gases $\left(\mathrm{N}_{2} \mathrm{O}\right.$ and $\left.\mathrm{CH}_{4}\right)$ and costs of air pollution. $\mathrm{CO}_{2} \mathrm{e}$ emissions were calculated using the production methodology, which meant that all the emissions within the system boundaries were taken into account, no matter whether the products were consumed locally or exported. The linear mixed integer optimization model developed in this paper is an updated version of the model presented in [24]. A detailed description of the variables and the corresponding units can be found in Nomenclature section. Only an excerpt from the whole model is presented in this section. All the equations of the developed optimization model can be found in Appendix B.

$$
\begin{aligned}
& \min Z=\sum_{i=1}^{n}\left(f i x_{-} O \& M_{i}+l e v_{i n v_{i}}\right) x_{i}
\end{aligned}
$$

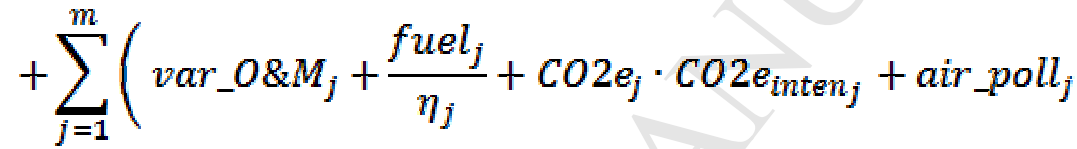

$$
\begin{aligned}
& \left.\cdot a i r_{-} p o l l_{\text {inten,j }}\right) x_{j}+\sum_{k=1}^{p}\left(g a s_{-} i m p_{-} \exp _{k}+\text { petr_imp }\right) x_{k} \\
& +\sum_{l=1}^{y} i n v_{e n, e f y} \cdot B_{y}
\end{aligned}
$$

As an example, the inequality constraint of the power balance is shown by eq.( 2 ). The electricity demand could be met by gas combined heat and power plant (CHP), biomass CHP, waste CHP, photovoltaics (PVs), wind turbines, solid-oxide full cells (SOFC) or from the battery storage ( 2 ). Additional electricity demand could be imposed from individual electric chillers, DC electric chillers, pumping needs for geothermal DC, reverse osmosis, electrified transport or charging the battery storage ( 2 ).

$$
\begin{aligned}
& x_{j, E L, g a s}+x_{j, E L, \text { biomass }}+x_{j, E L, \text { other }}+x_{j, \text { battery,storage_grid_dis }}+x_{j, g r i d \_b a t t e r y, s t o r a g e \_d i s} \\
& +S O F C-x_{j, \text { battery, storage }}-x_{j, g r i d_{\text {battery }}, \text { storage }_{c h}}-\frac{\text { chiller }_{D C}}{\operatorname{COP}_{D C_{\text {chiller }}}} \\
& -\frac{\text { chiller }_{\text {individual }}}{C O P_{\text {individual }}}-0.1 \cdot \text { geothermal }_{D C}-R O-\frac{S O E C}{\eta_{S O E C}}+\text { flex }- \text { flex }_{\text {ch }} \\
& \geq e l \_ \text {dem }
\end{aligned}
$$


314 One of the implemented environmental constraints in the model was the maximum allowed

$315 \quad \mathrm{CO}_{2} \mathrm{e}$ emissions, as shown by eq.( 3 ).

$\mathrm{CO} e_{\text {inten }_{j}} \cdot x_{j}+\mathrm{CO} e_{\text {inten }_{k}} \cdot x_{\text {petrol }} \leq \mathrm{CO} 2_{\text {cap }}$

\section{External costs of air pollution}

The calculation of regional-specific estimation of the air pollution external costs was based on data collected from the literature. This simplified approach was suitable since the purpose of the external costs was primarily to demonstrate their importance for the overall energy system modelling. For detailed analysis such calculation would require resource intensive impact pathway approach [26]. The data of energy external costs for Singapore were converted from the marginal external cost data for the United Kingdom [27], using the value transfer approach, as shown in eq. ( 4 ).

$a i r \_p o l l_{j}=M E C_{U K} \times\left(\frac{Y_{\text {Sing }}}{Y_{U K}}\right)^{e l a}$

Values for variables $Y_{\text {Sing }}$ and $Y_{U K}$ were obtained from The World Bank data [28] while the value of 0.32 for ela was directly adopted from the research on estimation of the health impact costs for particle pollution in Singapore [29].

\section{Case study and scenario development}

333 Singapore was chosen for the case study as it is a country that also represents a city, at a high 334 level of economic development and suitable for district cooling research, as it is located very 335 close to the equator.

$336 \mathrm{CO}_{2} \mathrm{e}$ emissions factors, capacities of energy facilities, energy demand and the description of 337 transportation sector can be found in great detail in [30] and [31]. Global warming potential of $338 \mathrm{CH}_{4}$ and $\mathrm{N}_{2} \mathrm{O}$ used in this case study were equivalent to 24 and 298 times $\mathrm{CO}_{2}$, respectively.

339 Singapore is currently rolling in a carbon tax scheme, which taxes $\mathrm{CO}_{2} \mathrm{e}$ emissions at fixed 340 rate. The proposed carbon tax, which is anticipated starting from the year 2019, is estimated 341 between 10 and 20 SGD [32]. The projected price for the year 2030 used in this study was 35 342 SGD (21.6 EUR), in line with the expected relative increase of the price of the $\mathrm{CO}_{2}$ allowance 343 in the European Union [33].

344 Air pollution factors that were used in the model are presented in Table 1. 
Table 1. Emissions of air pollutants from different technologies and fuels in the years 2015 and 2030 (references refer to the entire row unless otherwise stated in a specific cell)

\begin{tabular}{l|lllll|lllllll}
\hline \multirow{2}{*}{$(\mathrm{g} / \mathrm{GJ})$} & \multicolumn{5}{|c|}{2015} & \multicolumn{7}{c}{2030} \\
\cline { 2 - 9 } & $\mathrm{NO}_{\mathrm{x}}$ & $\mathrm{SO}_{\mathrm{x}}$ & $\mathrm{CH}_{4}$ & $\mathrm{~N}_{2} \mathrm{O}$ & $\mathrm{PM}$ & $\mathrm{NO}_{\mathrm{x}}$ & $\mathrm{SO}_{\mathrm{x}}$ & $\mathrm{CH}_{4}$ & $\mathrm{~N}_{2} \mathrm{O}$ & $\mathrm{PM}$ & $\mathrm{Ref}$ \\
\hline Gas boiler & $10-13$ & 0 & 3 & 1 & $0,1[34]$ & $8-11$ & 0 & 3 & 1 & $0,1[34]$ & {$[35]$} \\
Gas CHP & 48 & 0 & 1,5 & 1 & $0,05[34]$ & 42 & 0 & 1,5 & 1 & $0,05[34]$ & {$[35]$} \\
Biomass boiler & 81 & 1,9 & 0 & 0,8 & $10[34]$ & 81 & 1,9 & 0 & 0,8 & $10[34]$ & {$[35]$} \\
Biomass CHP & 81 & 1,9 & 0 & 0,8 & $4,82[34]$ & 81 & 1,9 & 0 & 0,8 & $4,82[34]$ & {$[35]$} \\
Waste CHP & 124 & 0 & 0,59 & 1,2 & $0,29[34]$ & 30 & 0 & 0,59 & 1,2 & $0,29[34]$ & {$[35]$} \\
Gasoline & 187 & 0 & 7 & 18 & $1,72[36]$ & 187 & 0 & 7 & 18 & $1,72[36]$ & {$[37]$} \\
Methanol & 29,915 & 0 & 0 & 0 & 0 & 6,94 & 0 & 0 & 0 & 0 & {$[38]$} \\
\hline
\end{tabular}

Marginal external costs for air pollution can be seen in Table 2. Costs differ according to the pollutant type and source of the pollution. The latter is divided into two groups, stationary such as energy plants and non-stationary sources such as transport sector.

Table 2. Marginal external costs in Singapore for 2015, point and non-point sources of pollution €/ton

\begin{tabular}{l|lllll}
\hline $\begin{array}{l}\text { Air } \\
\text { pollution }\end{array}$ & Sector & Low & High & Medium & Ref \\
\hline $\mathrm{NO}_{\mathrm{X}}$ & Energy generation (Point) & 735 & 2,943 & $\mathbf{1 , 8 3 9}$ & {$[27]$} \\
& Transport (Non-point) & 14,708 & 58,838 & $\mathbf{3 6 , 7 7 4}$ & {$[27]$} \\
$\mathrm{SO}_{\mathrm{X}}$ & Energy generation (Point) & 2,762 & 3,887 & $\mathbf{3 , 4 1 9}$ & {$[27]$} \\
& Transport (Non-point) & 7,549 & 11,324 & $\mathbf{9 , 9 3 3}$ & {$[39]$} \\
$\mathrm{PM}$ & Energy generation (Point) & 3,977 & 5,772 & $\mathbf{5 , 0 7 7}$ & {$[27]$} \\
& Transport (Non-point) & 79,527 & 115,424 & $\mathbf{1 0 1 , 5 7 2}$ & {$[27]$} \\
\hline
\end{tabular}

* Adjusting damage cost value over time accounting for $2 \%$ uplift is taken into account for the implementation of the values in the model [27]

Different levels of marginal cost values, i.e. low, high and medium were calculated to tackle the issue of the limitation that arises from different valuation of health and environment. The valuation is specific to location and culture and therefore it may limit the reliability of the value transfer approach. For the purpose of this paper, the medium value of marginal external costs value was selected as the input for the optimization model, in order to follow the approach that was taken in the previous research [40]. Moreover, in order to check the extreme cases of the air pollution socio-economic impact, a sensitivity analysis was carried out with the low and high air pollution cost levels. The results of the sensitivity analysis have been discussed in the Discussion section.

Both air pollution costs and environmental costs $\left(\mathrm{CO}_{2} \mathrm{e}\right.$ emissions) were internalized in the model. By taking the latter approach, a recommendation from the Oxford Institute for Energy Studies was followed, claiming that the energy modelling should be technology neutral after internalizing environmental externalities [41].

Most of the economic and technical data for the predefined technologies were obtained from the technology datasheet published by Energinet.dk, the Danish transmission system operator [42]. Moreover, an overview of the investment costs, as well as fixed and variable operating 
and maintenance costs for most of the technologies predefined in this model can be seen in [24]. The techno-economic data used for reversible osmosis technology was obtained from [43]. There are two main absorption chillers technologies, LiBr-water and water-ammonia ones. A detailed overview of absorption technologies, technical constraints, investment costs and expected development can be found in [44]. A single effect LiBr-water absorption technology for DC was assumed in this paper. Assumed thermal COP of those chillers was 0.7 , at heat source temperature between $90-95{ }^{\circ} \mathrm{C}$ [23]. The typical capacity of a sinle unit single-effect $\mathrm{LiBr}$-water absorption chillers is $5-7000 \mathrm{~kW}$ and it is typically used for cooling in industry and large-scale district cooling [44]. The investment cost of large scale LiBr-water absorption chillers used in this study was $120,000 € / \mathrm{MW}_{\mathrm{c}}$ [24].

\section{Scenarios validation}

In order to ensure that the model was performing well, the business as usual (BAU) scenario was validated against the projection of the energy system modelled in EnergyPLAN [31]. The main indicators of scenario validation are summarized in Table 3. It can be seen that the BAU scenario can be validated against the EnergyPLAN model.

Table 3. Comparison of the results in the current model and the projections modelled in EnergyPLAN simulation software for the year 2030

\begin{tabular}{l|lll}
\hline & $\begin{array}{l}\text { Projection from the } \\
\text { reference [31] (TWh) }\end{array}$ & $\begin{array}{l}\text { Scenario 1 BAU (TWh) } \\
\text { (This study) }\end{array}$ & Difference \\
\hline $\mathrm{CO}_{2}$ emissions & 50.7 & 49.1 & $3.3 \%$ \\
$\mathrm{PES}$ & 223.7 & 208.3 & $6.9 \%$ \\
\hline
\end{tabular}

A relatively large difference of $6.9 \%$ is still tolerable keeping in mind the statistical uncertainties about the future projections of the BAU scenario.

In order to validate the assumption used to calculate the external costs of the air pollution, the results for Singapore were validated against the air pollution external costs of a country with similar population, i.e. Norway. The economic cost due to the health issues caused by air pollution in Norway was 700 million EUR (calculated from 2010USD) [45]. The negative externality due to air pollution in Singapore was calculated to be 682 million EUR in the BAU case and the result can be seen in Table 8. Emissions of $\mathrm{CO}_{2} \mathrm{e}$, pollutants and particles and respective socio economic costs of themHence, the calculated air pollution caused externality can be considered as validated.

\section{Analysis of the scenarios}

The scenarios developed in this paper represent a stepwise integration of renewable energy based technologies, each step representing a higher degree of systems integration and for the Scenarios 6 and 7 additional $\mathrm{CO}_{2}$ e limitation. Scenarios 2 to 6 were modelled with constrains for PV and the solar thermal capacity due to the space availability, while only the Scenario 7 was left without such constraints. This was done in order to show the impact of seeking for self-sustainability within the city (Scenario 2-6) versus utilizing the energy outside from the city borders (Scenario 7). A detailed representation of scenarios can be seen in Table 4. All scenarios were developed for the energy system anticipated in the year 2030. 
Table 4. Representation of scenarios according to the implemented technologies or $\mathrm{CO}_{2} \mathrm{e}$ emission limitation (all scenarios developed for the year 2030)

\begin{tabular}{|c|c|c|c|c|c|c|c|}
\hline Technologies/constraints & $\begin{array}{l}\text { Scenario } \\
1 \\
\text { BAU }\end{array}$ & $\begin{array}{l}\text { Scenario } \\
2 \\
\text { DC }\end{array}$ & $\begin{array}{l}\text { Scenario } \\
3 \\
\text { DC-PV }\end{array}$ & $\begin{array}{l}\text { Scenario } \\
4 \\
\text { DC-PV- } \\
\text { el.transp. }\end{array}$ & $\begin{array}{l}\text { Scenario } \\
5 \\
\text { DSM- } \\
\text { EnEff }\end{array}$ & $\begin{array}{l}\text { Scenario } \\
6 \\
\mathrm{CO}_{2}\end{array}$ & $\begin{array}{l}\text { Scenario } \\
7 \\
\text { non self- } \\
\text { sufficient }\end{array}$ \\
\hline Transport Electrification & $\checkmark{ }_{a}$ & $\checkmark a$ & $\checkmark a$ & $\checkmark$ & $\checkmark$ & $\checkmark$ & $\checkmark$ \\
\hline Photovoltaics & $\checkmark \mathrm{b}$ & $\checkmark \mathrm{b}$ & $\checkmark$ & $\checkmark$ & $\checkmark$ & $\checkmark$ & $\checkmark \mathrm{d}$ \\
\hline District Cooling & & $\checkmark$ & $\checkmark$ & $\checkmark$ & $\checkmark$ & & $\checkmark$ \\
\hline $\begin{array}{l}\text { SOFC, SOEC, synthetic } \\
\text { fuels } \\
\text { DSM and buildings } \\
\text { energy efficiency } \\
\mathrm{CO}_{2 \mathrm{e}} \text { emissions }\end{array}$ & & & & $\checkmark$ & $\begin{array}{l}\checkmark \\
\checkmark\end{array}$ & & $\begin{array}{l}\checkmark \\
\checkmark \\
\checkmark c\end{array}$ \\
\hline
\end{tabular}

${ }^{\mathrm{a}}$ Maximum $10 \%$ of gasoline demand shifted to electrified transport (other scenarios did not have an upper limit on transport electrification rate)

${ }^{\mathrm{b}}$ Maximum installed capacity of PVs equal to 1,000 MW

${ }^{\mathrm{c}} \mathrm{CO}_{2} \mathrm{e}$ emissions constrained to $13.1 \mathrm{Mt}$ which is equal to $40 \%$ reduction of $\mathrm{CO}_{2 \mathrm{e}}$ emissions in 2030 compared to 1990 level

${ }^{\mathrm{d}} \mathrm{PV}$ and solar thermal not constrained. This scenario represents the city that receives a portion of energy, generated from PVs and solar thermal energy, which are located outside of the city.

The scenarios were developed in this specific order in order to detect the system impact of integration of specific energy sector and/or technologies. Furthermore, the developed optimization model is suitable for analysing complex interactions between different energy sectors. Specific technologies that integrated different sectors in this case study were: electric chillers in district cooling, waste heat from power plants as an input for absorption chillers, reversible osmosis for desalination of water, SOEC and SOFC and vehicles to grid technology. Furthermore, no less than five different storage technologies were modelled in this case study, as shown in Table 9.

The scenarios differed according to the combination of introduced energy technologies where the last two scenarios were additionally constrained with the limitation on $\mathrm{CO}_{2} \mathrm{e}$ emissions. The additional $\mathrm{CO}_{2} \mathrm{e}$ constraint corresponds to the $40 \%$ reduction in $\mathrm{CO}_{2} \mathrm{e}$ emissions compared to the 1990 level. The latter assumption was implemented in order to assess the costs of implementing policy similar to that of the European Union, although its environmental policy is stricter than the current Singapore's goals.

For each scenario, the impact on energy supply, the economy and the environment was assessed. The impact on the energy supply was represented as primary energy supply (PES, equal to the primary energy demand). For the economic indicator, the total annual socioeconomic cost of the energy system was calculated. Even though the contribution of indicators related to job creation is recognised to be beneficial in smart energy systems [46], it remained out of the scope of this paper. Environmental impact was estimated on the basis of four different indicators given as emissions of air polluting gases $\left(\mathrm{NO}_{\mathrm{x}}\right.$ and $\left.\mathrm{SO}_{\mathrm{x}}\right)$, greenhouse gases $\left(\mathrm{CH}_{4}, \mathrm{~N}_{2} \mathrm{O}\right.$ and $\mathrm{CO}_{2}$, reported as $\left.\mathrm{CO}_{2 \mathrm{e}}\right)$ and particulate matter $(\mathrm{PM})$ as shown in Table 1 .

The model presented here has the capability of modelling all four flexibility sources in the energy system, i.e. electricity import/export over the system boundaries, power-to-heat and 
power-to-gas, energy storage and demand response in industry and households. However, for this specific case study electricity import/export was not allowed, due to the current energy security policy of Singapore. The other three flexibility sources were modelled for this specific case study. The potential error caused by not implementing the electricity import/export possibility over the city borders as another source of flexibility was assessed by carrying out a sensitivity analysis, results of which have been presented and discussed in the discussion section.

The demand side management was introduced for industry and household sectors. The variables that were used in the model can be seen in Table 5. The load management factor is defined as the share of the displaceable power at the overall power demand of a particular application. The factor includes both technical limitations arising from the process, as well as technical limitations arising from different uses.

Table 5. Demand side management values for industry and households

\begin{tabular}{|c|c|c|c|c|}
\hline Sector & $\begin{array}{l}\text { Load management } \\
\text { factor }(\%)\end{array}$ & $\begin{array}{l}\text { Max } \\
\text { duration (h) }\end{array}$ & $\begin{array}{l}\text { Frequency of the } \\
\text { activation in a year }\end{array}$ & $\begin{array}{l}\text { Price } \\
(\text { EUR/MW) }\end{array}$ \\
\hline \multicolumn{5}{|l|}{ Industry } \\
\hline Chemical industry [18] & 30 & 4 & 40 & $87,318[47]$ \\
\hline Petroleum refining [47] & 15 & 4 & $\mathrm{n} / \mathrm{a}$ & $87,318[47]$ \\
\hline \multicolumn{5}{|l|}{ Households } \\
\hline Water heater [18] & 25 & 2 & 220 & $20,075[48]$ \\
\hline Refrigerator and freezer [18] & 33 & $2^{a}$ & 365 & $15,400[48]$ \\
\hline
\end{tabular}

452 The description of energy efficiency measures can be found in [49]. Energy efficiency options $453 \mathrm{~A}, \mathrm{~B}, \mathrm{C}$ and D, that can be found in [49], were predefined in the optimization model and 454 denoted as energy efficiency options A to D, as shown in Table 6. Measures are divided into 4554 options according to the percentage of resulting electricity savings and costs arising from 456 the implementation of each option. Table 6 represents the main indicators which were used in 457 the model to select the best energy efficiency scenario.

458 Table 6. Indicators of different energy efficiency scenarios for buildings

\begin{tabular}{c|ll}
\hline $\begin{array}{l}\text { Energy efficiency } \\
\text { options }\end{array}$ & Electricity savings (\%) & Capital cost per savings (EUR/MWh) \\
\hline A & 0 & - \\
B & $4.60 \%$ & 15.6 \\
C & $22.30 \%$ & 5.3 \\
D & $28.40 \%$ & 61.4 \\
\hline
\end{tabular}

459 Capital costs were modelled using binary variables denoting existing/non-existing investment. 460 The latter means that if the model chose to invest in a certain energy efficiency option, the 461 whole investment amount for the whole year of energy savings would occur in the model. It 462 was not possible to achieve savings only in certain hours of the year, as majority of the 463 investment costs for increased energy efficiency are fixed ones. 


\section{Specific constraints for the case of Singapore}

There were several specific constraints that were implemented for the case of the city of Singapore. First, in scenarios 3-6, the PV capacity was constrained to 9,450 MW, which can be installed on all the rooftops throughout the city [50]. In scenarios 1-6, the solar thermal capacity was constrained to $1,700 \mathrm{MW}$, which represents $0.5 \%$ of the land area in the city. Only the last scenario (non self-sufficient) allowed for unconstrained installation of PV and solar thermal technology. In reality, the latter would mean that those installations would need to be installed outside of the city borders. However, it was useful scenario for evaluation of potential socio-economic costs and air pollution when focusing on self-sustainability versus allowing the energy system of a city to be integrated with the surrounding area.

Geothermal energy was constrained to $400 \mathrm{MW}_{\text {th }}$, as this was the amount of geothermal potential found in the literature [51]. Waste incineration plant was narrowly constrained so that it could incinerate only the waste generated in the area. The latter approach led to the possible capacity of waste CHP plant from $161 \mathrm{MW}$ to $170 \mathrm{MW}$, with steady operation throughout the year.

Singapore does not have a potential for significant amounts of sustainable biomass to be utilized in the CHP plant. Hence, it was assumed that all the biomass that was needed for the operation of biomass CHP originated from sea algae, increasing the overall cost of the energy system.

Nevertheless, on average, 200 million gallons a day of desalinated water needed to be produced via reversible osmosis, in line with the envisaged policy for the year 2030 [52].

\section{Results}

This section presents the results and the following analyses of seven different scenarios for the energy system of Singapore. It is important to note that the evaluation of the air pollution emissions in this section does not include air pollutant emissions from the industrial energy consumption, and related internalized external costs of air pollution from the industry. Furthermore, the total energy consumption in the industrial sector was not optimized inside the optimization model due to the lack of available data. They were considered to be fixed, i.e. yearly rise in the industry energy consumption due to the economic growth, is expected to be cancelled out with the energy efficiency measures that will be undertaken in the industry [53], keeping primary energy consumption and emissions in the industrial sector flat. The only assumed change was that by the year 2030 the oil consumption of the industry will be replaced with natural gas (or liquefied natural gas) consumption.

Primary energy supply displayed in Figure 3 was an important indicator for the energy system evaluation, as it shows the integration level of RES. Higher RES penetration level is supported by synergies between different energy sectors, i.e. power system, cooling sector, gas grid and transport sector. The lowest PES value occurred in Scenario 5 (DSM-EnEff) and it was $20 \%$ lower than the value in the BAU scenario. Fossil fuel supply was the lowest in scenarios 6 and 7, in which it represented 34\% and 30\% of the total primary energy supply, respectively. 
Several issues concerning the Figure 3 need to be clarified. First, one can note that scenarios 2-5 have stepwise reductions in PES compared to the BAU scenario. There were several reasons for those energy savings. First, district cooling helped utilizing waste heat from waste incineration, biomass and gas CHP plants. Second, electrification of the transport significantly increased its efficiency as electric vehicles have approximately three times better efficiency compared to the gasoline vehicles [54]. Third, energy efficiency scenario $\mathrm{C}$ from Table 6, adopted in scenarios 5-7, reduced cooling energy demand for $22.3 \%$, which can be seen in Figure 2.

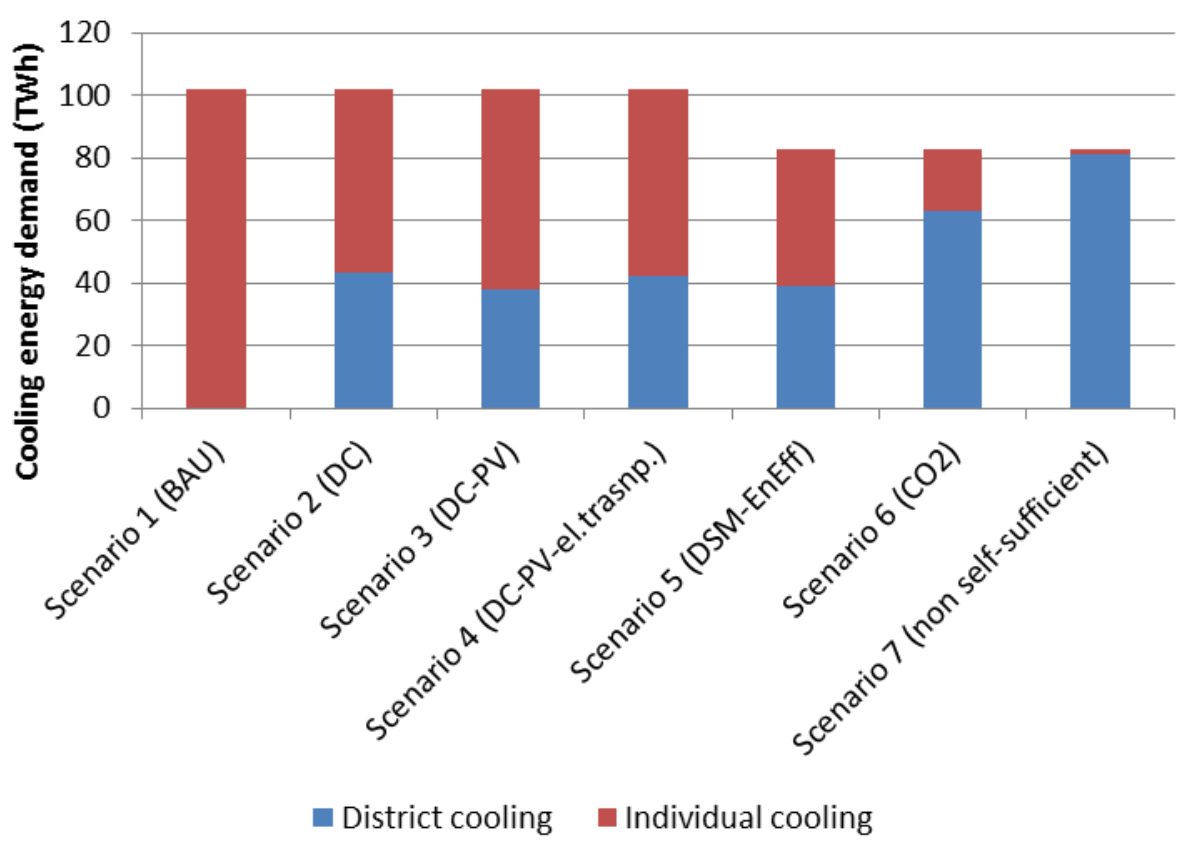

Figure 2. District cooling versus individual cooling share in different scenarios

It can be further noted from Figure 3 that in scenarios 6 and 7, although they have the lowest fossil fuel supply, their PES is higher than in other scenarios. In scenario 6, the main reason is that due to the $\mathrm{CO} 2 \mathrm{e}$ constraint, $64 \%$ of final energy demand for electricity was met from biomass CHPs, which had lower electrical efficiency compared to the gas CHPs, 29\% compared to 50\%. The latter caused larger demand for PES. In scenario 7, one part of increased PES originated from the higher biomass demand than in scenario $1-5$, as $11 \%$ of final electricity demand is met by biomass CHP. More important reason is that the scenario 7 had the largest share of DC out of all scenarios, as $98 \%$ of the total cooling demand was met by DC, which can be seen from Figure 2. DC mostly utilized low grade heat via absorber units, and most of this heat was generated by solar thermal units. Although this renewable heat is cheap from the socio-economic point of view, absorption units had COP of only 0.7 and thus, the demand for PES was relatively high. On the other hand, meeting cooling energy demand via individual cooling in other scenarios was met by individual electric chillers with COP value of 3. As in scenarios 2-5 most of electricity was generated by gas CHPs with electrical efficiency of 50\%, the resulting PES was lower than in scenario 7. Moreover, PES in scenario 7 was only $2.4 \%$ larger than in BAU scenario. 
It is interesting to observe the optimal shares of district cooling, one of the endogenous decisions of the optimization model in Figure 2. The optimal share of DC in scenarios 2-5 was between $37 \%$ and $47 \%$. As some of the constraints imposed in the model were capacities of solar thermal and geothermal energy, due to the space availability and geothermal potential, there was not enough of cheap heat available in the system. Hence, for the part of the cooling demand that could not be satisfied via available cheap heat from geothermal, solar thermal or CHP plants and absorption units, it was more efficient to satisfy the cooling demand using electricity driven individual chillers with COP value of 3. Only in the last two scenarios DC shares increased significantly, to $76 \%$ and $98 \%$, respectively. For the scenario 6 , the reason was that there was more available heat from biomass CHP units, which were erected instead of gas CHPs, in order to meet the tight $\mathrm{CO}_{2} \mathrm{e}$ constraint. As biomass CHP had lower electrical efficiency compared to the gas CHPs, consequently it generated more heat per unit of electricity generated than the gas CHP. In the Scenario 7, as there was no constraint on the capacity of solar thermal capacity, this was the cheapest option to produce heat which fed absorption units to produce cold for meeting cooling energy demand.

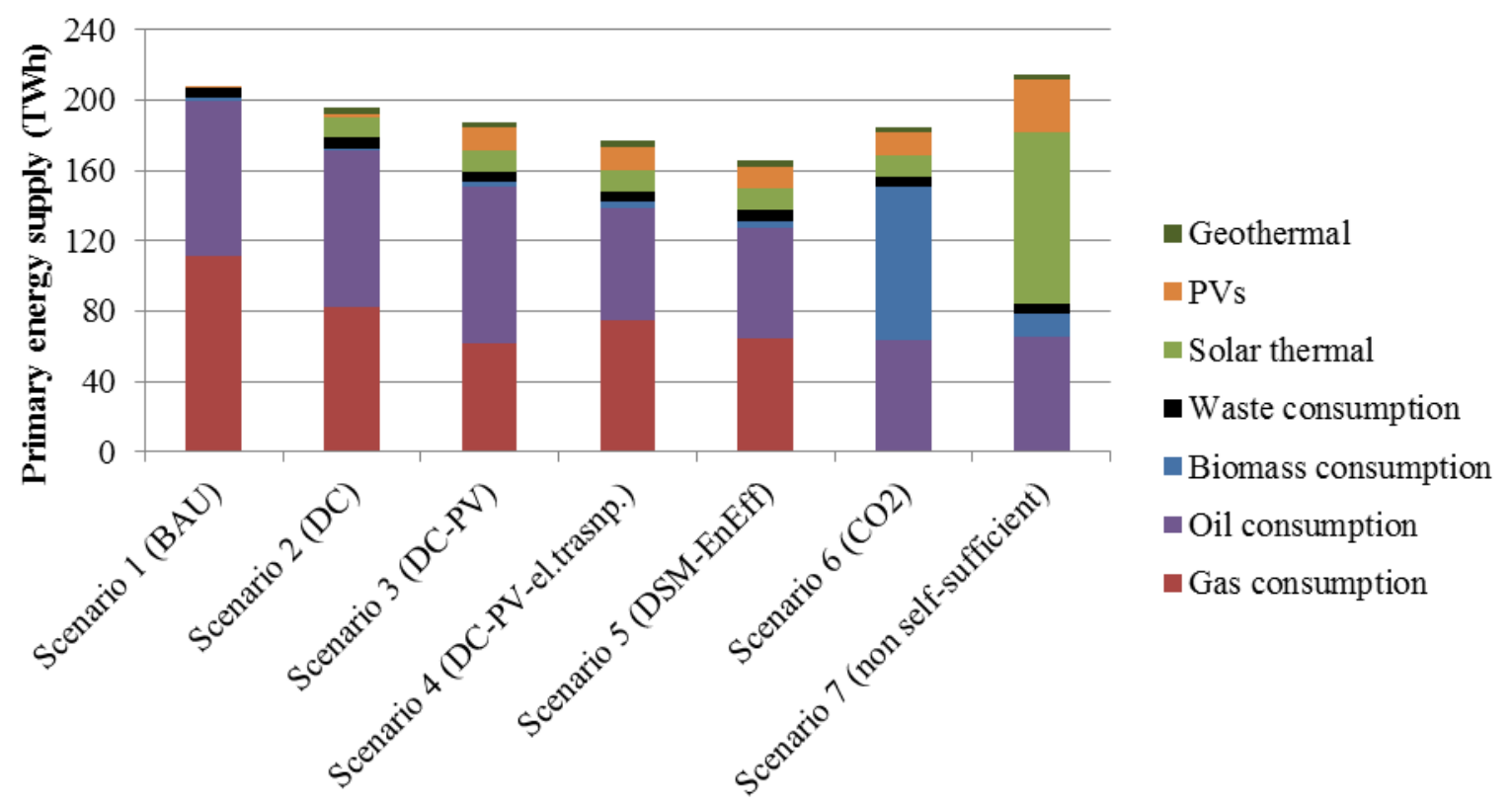

Figure 3. Primary energy supply by fuel (63.4 TWh of oil supply in scenarios 1 to 5 belongs to industry, which was not optimized within the model. 63.4 TWh of gas supply in scenarios 6 and 7 belongs to industry sector)

549 It is interesting to observe changes in electricity generation in different scenarios according to the share of the specific generation source as shown in Figure 4 and according to the real values of the generated electricity as shown in Table 7. Constraints imposed on the $\mathrm{CO}_{2} \mathrm{e}$ emissions in Scenario 6 (CO2 scenario) resulted in biomass substituting natural gas for energy production. The latter resulted in the biomass CHP share in electricity generation of $64 \%$ in Scenario 6 (CO2 scenario). As Singapore had no sustainable biomass sources, all the biomass originated from sea algae production making the energy system more expensive. In scenario 7, the one which did not have a cap on PV capacity, it was shown that it is optimal to meet a significant $80 \%$ of final electricity demand by photovoltaics. Two main reasons are that it 
558 correlates the cooling energy demand, as well as the steady solar irradiation throughout the 559 whole year as Singapore does not have distinct seasons during the year. Scenario 7 also had $560434 \mathrm{MW}$ of installed SOFC, as well as 1,826 MW of SOEC, which served as a source of 561 flexibility in the system with a large share of PV electricity generation. Furthermore, another 562 technology that fostered integration of significant share of PV generation in the system was 563 centralized electric chillers, used for district cooling supply. In scenario 7, absorbers in DC 564 system had the capacity of $11,187 \mathrm{MW}$, while centralized electric chillers had the capacity of $5651,258 \mathrm{MW}_{\text {th }}(\mathrm{COP}=5)$.

566 567

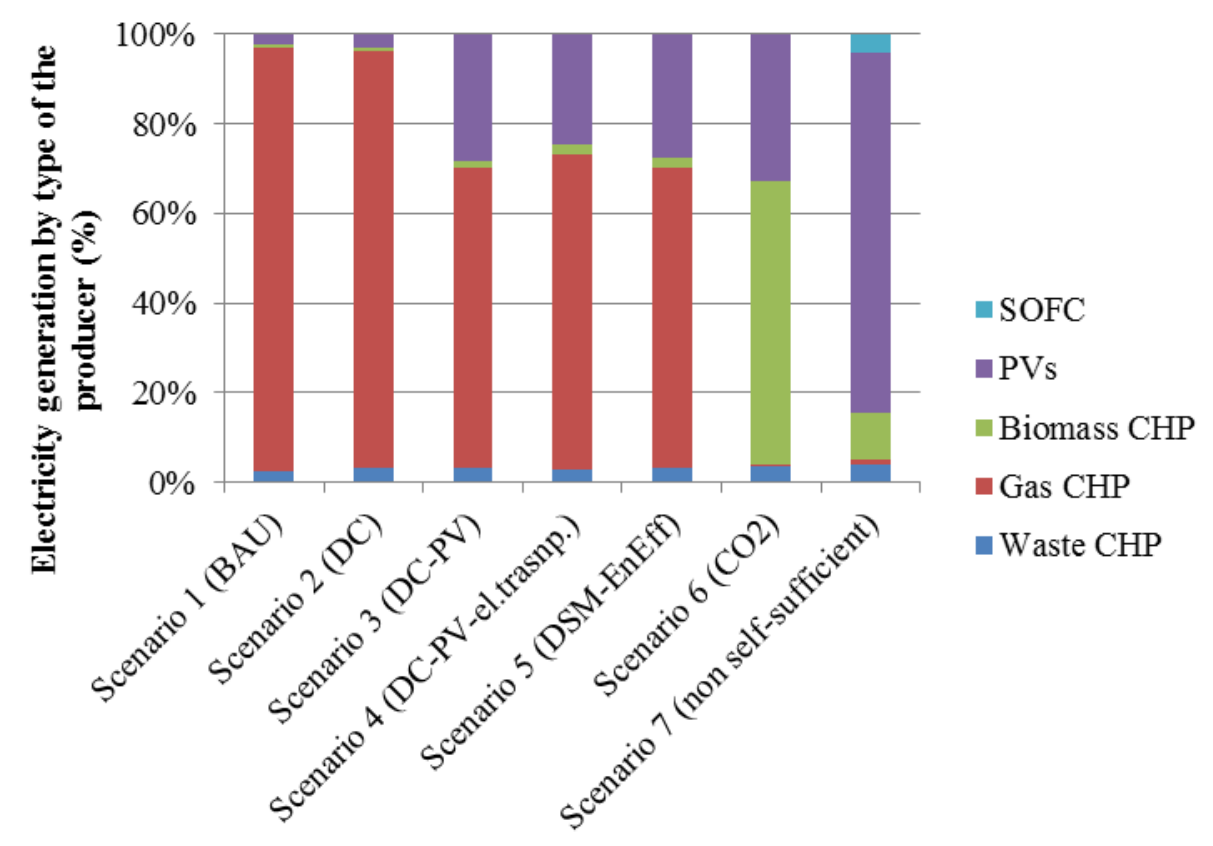

\begin{tabular}{l|ccccccc}
\hline & $\begin{array}{l}\text { Scenario } \\
1 \\
\text { BAU }\end{array}$ & $\begin{array}{l}\text { Scenario 2 } \\
\text { DC }\end{array}$ & $\begin{array}{l}\text { Scenario 3 } \\
\text { DC-PV }\end{array}$ & $\begin{array}{l}\text { Scenario 4 } \\
\text { DC-PV- } \\
\text { el.transp. }\end{array}$ & $\begin{array}{l}\text { Scenario 5 } \\
\text { DSM- } \\
\text { EnEff }\end{array}$ & $\begin{array}{l}\text { Scenario 6 } \\
\mathrm{CO}_{2}\end{array}$ & $\begin{array}{l}\text { Scenario 7 } \\
\text { non self- } \\
\text { sufficient }\end{array}$ \\
\hline Waste CHP & 1.41 & 1.49 & 1.49 & 1.49 & 1.49 & 1.49 & 1.41 \\
Gas CHP & 55.48 & 41.15 & 31.01 & 37.42 & 32.10 & 0.02 & 0.47 \\
Biomass & 0.33 & 0.35 & 0.64 & 1.09 & 1.04 & 25.23 & 3.81 \\
CHP & 1.39 & 1.39 & 13.04 & 13.11 & 13.10 & 12.99 & 29.54 \\
PVs & 0.00 & 0.00 & 0.00 & 0.00 & 0.00 & 0.00 & 1.50 \\
SOFC & 58.62 & 44.38 & 46.19 & 53.11 & 47.73 & 39.74 & 36.74 \\
\hline
\end{tabular}

Figure 4. Shares of electricity generation sources by type

Table 7. Mix of electricity generation sources (TWh) 
In Table 8, selected emissions are summarized indicating that higher share of DC, RES and the integration of different sectors resulted in lower $\mathrm{CO}_{2} \mathrm{e}$ emissions. It is worth noting here that 13.1 Mt of $\mathrm{CO}_{2} \mathrm{e}$ emissions, out of the total reported emissions in Table 8, originated from the industrial consumption, which was not optimized inside the model. Opposite to this declining trend for $\mathrm{CO}_{2}$ emissions, air pollution trend was not so straightforward and its values varied across different scenarios. The scenario with a constraint on $\mathrm{CO}_{2} \mathrm{e}$ emissions $\left(\mathrm{CO}_{2}\right.$ scenario) had PM emissions 7.4 times higher than in the BAU scenario. NOx emissions followed declining trend except in the case where $\mathrm{CO}_{2} \mathrm{e}$ was limited.

It can be further noted from Table 8 that although air pollution emissions in Scenario 6 were much larger than in scenarios 1 to 3, the resulting socio-economic cost was much lower. The reason is that the majority of the air pollution emissions in Scenario 6 originated from biomass CHP plants, which represented the point-source pollutant, which can be better handled than the non-point source pollutants. On the other hand, in scenarios 1 to 3, the majority of emissions originated from gasoline use in vehicles, which represent the non-point source of pollution, for which health externalities are much costlier than for the point source 585 pollutants.

Table 8. Emissions of $\mathrm{CO}_{2} \mathrm{e}$, pollutants and particles and respective socio economic costs of them

\begin{tabular}{|c|c|c|c|c|c|c|c|}
\hline & $\begin{array}{l}\text { Scenario } \\
1 \\
\text { BAU }\end{array}$ & $\begin{array}{l}\text { Scenario } \\
2 \\
\text { DC }\end{array}$ & $\begin{array}{l}\text { Scenario } \\
3 \\
\text { DC-PV }\end{array}$ & $\begin{array}{l}\text { Scenario } \\
4 \\
\text { DC-PV- } \\
\text { el.transp. }\end{array}$ & $\begin{array}{l}\text { Scenario } \\
5 \\
\text { DSM- } \\
\text { EnEff }\end{array}$ & $\begin{array}{l}\text { Scenario } \\
6 \\
\mathrm{CO}_{2}\end{array}$ & $\begin{array}{l}\text { Scenario } \\
7 \\
\text { non self- } \\
\text { sufficient }\end{array}$ \\
\hline NOx $(\mathrm{t})$ & 34,957 & 30,676 & 27,902 & 13,245 & 11,571 & 26,177 & 4,612 \\
\hline SOx (kg) & 7,874 & 8,311 & 15,168 & 25,755 & 24,542 & 595,024 & 89,864 \\
\hline PM (kg) & 204,358 & 200,651 & 214,396 & 86,778 & 81,651 & $1,517,194$ & 234,308 \\
\hline $\begin{array}{l}\mathrm{CO}_{2} \mathrm{e} \\
(\mathrm{Mt})\end{array}$ & 44 & 38 & 34 & 29 & 27 & 14 & 14 \\
\hline $\begin{array}{l}\text { Socio- } \\
\text { economic } \\
\text { cost: air } \\
\text { pollution } \\
\text { (mil €) }\end{array}$ & 682 & 674 & 669 & 31 & 27 & 63 & 10 \\
\hline $\begin{array}{l}\text { Socio- } \\
\text { economic } \\
\text { cost: } \mathrm{CO}_{2} \mathrm{e} \\
\text { emissions } \\
(\mathrm{mil} € \text { ) }\end{array}$ & 910 & 787 & 700 & 614 & 568 & 292 & 294 \\
\hline
\end{tabular}




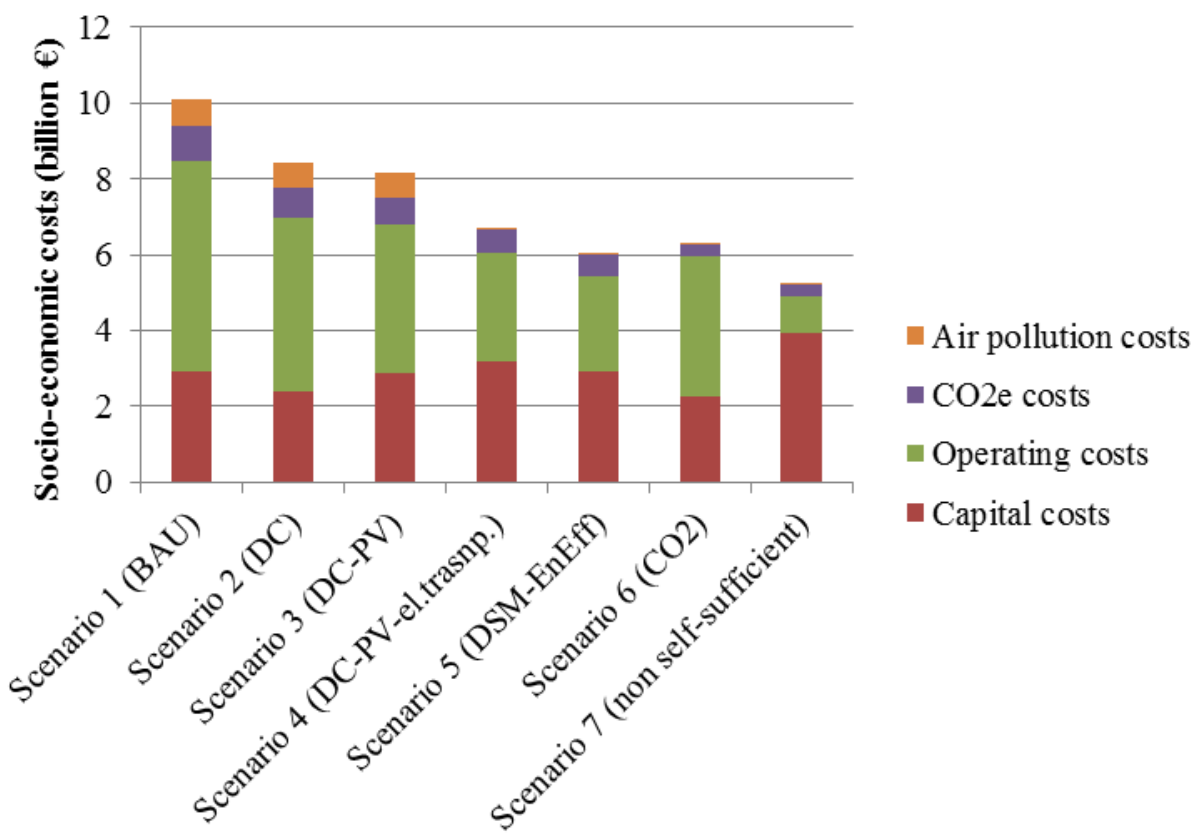

Figure 5. The total socio-economic costs in different scenarios

591 The total socio-economic costs of Scenarios 2-7 were $16 \%$ to $48 \%$ lower than in the BAU 592 scenario as shown in Figure 5. Scenario 6 (CO2 scenario) did not follow the same decreasing 593 trend and it had costs higher than Scenario 4 (DC-PV-el.transp.) and Scenario 5 (DSM594 EnEff), still 37\% lower than BAU scenario. The increased costs in Scenario 6, compared to 595 the scenarios 4 and 5, showed that tight constraints on the $\mathrm{CO}_{2} \mathrm{e}$ emissions can result in a 596 slightly higher socio-cost, although the carbon tax was already accounted for in the reported 597 socio-economic costs. On the other hand, Scenario 7 shows that not seeking for self598 sustainability of cities, but rather also utilizing the resources from the surroundings, can bring 599 the costs down, in line with the increase in the penetration of renewable energy sources and 600 decreased carbon and air pollution emissions. 


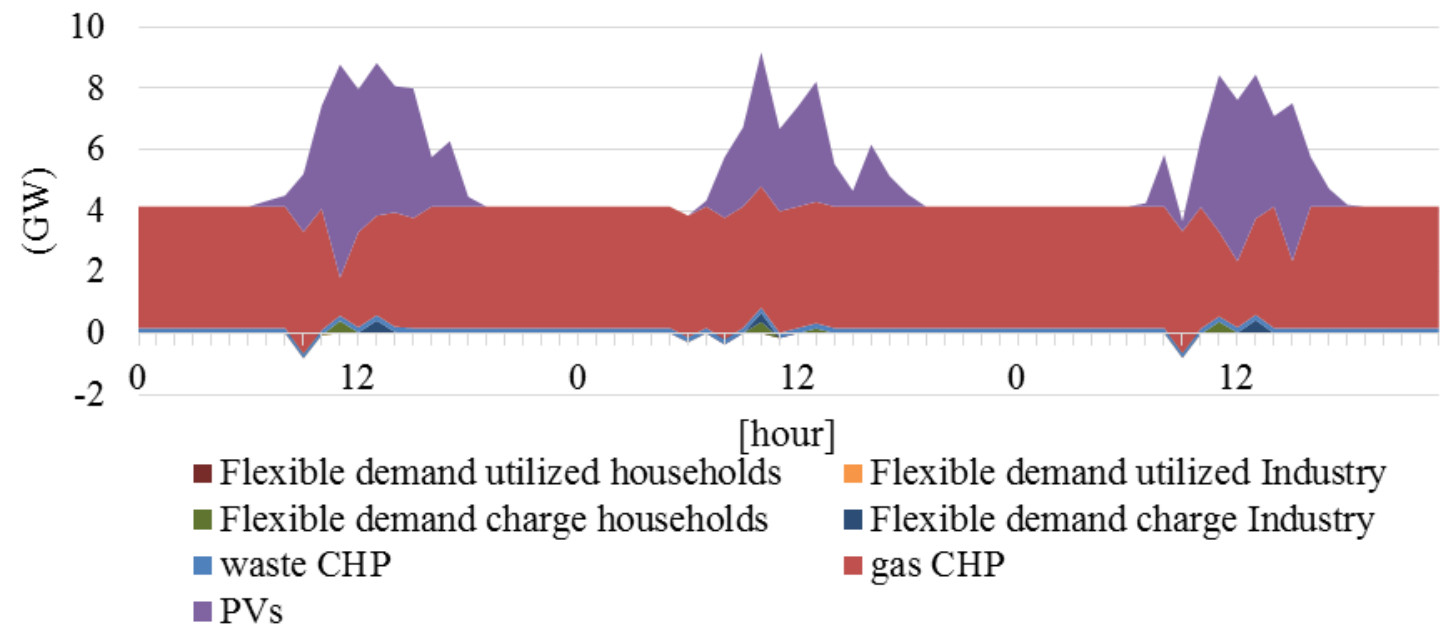

604 Figure 6. Hourly electricity generation mix in DSM-EnEff (Scenario 5) from the $07^{\text {th }}$ to the $6059^{\text {th }}$ of July

606 Figure 6 represents hourly electricity generation mix on the chosen days in Scenario 5 (DSM607 EnEff). One can note that the shifted load (Flexible demand utilized industry and Flexible 608 demand utilized households) occurred just before the peak PV generation. Although usually 609 the role of DSM is to reduce the peak demand, in this case peak demand was actually 610 increased due to the flexible demand. The reason was that the peak demand closely matched 611 the increased PV generation. Waste CHP had constant generation due to the constraints of 612 consuming all the supplied waste. Outside the PV generation periods, most of the demand was 613 met by gas CHPs.

\section{Usage of different storages}

615

616 Different storage solutions were modelled and the optimal capacities of different storage types 617 is shown in Table 9. The detailed hourly operation of different storage types can be found in 
Table 9. Total capacities of different storage types (GWh)

\begin{tabular}{|c|c|c|c|c|c|c|c|}
\hline & $\begin{array}{l}\text { Scenario } \\
1 \mathrm{BAU}\end{array}$ & $\begin{array}{l}\text { Scenari } \\
\text { o } 2 \text { DC }\end{array}$ & $\begin{array}{l}\text { Scenario } \\
3 \text { DC-PV }\end{array}$ & $\begin{array}{l}\text { Scenario } \\
4 \\
\text { DC-PV- } \\
\text { el.transp. }\end{array}$ & $\begin{array}{l}\text { Scenario } \\
5 \text { DSM- } \\
\text { EnEff }\end{array}$ & $\begin{array}{l}\text { Scenari } \\
\text { o } 6 \\
\mathrm{CO}_{2}\end{array}$ & $\begin{array}{l}\text { Scenario } \\
7 \\
\text { non } \\
\text { self- } \\
\text { sufficien }\end{array}$ \\
\hline $\begin{array}{l}\text { Pit Thermal } \\
\text { Energy Storage } \\
\text { (PTES) }\end{array}$ & 0 & 153 & 297 & 163 & 151 & 76 & 492 \\
\hline $\begin{array}{l}\text { Grid battery } \\
\text { storage }\end{array}$ & 5.9 & 0 & 0 & 0 & & 0 & 20.6 \\
\hline $\begin{array}{l}\text { Syngas } \\
\text { storage }\end{array}$ & 0 & 0 & 0 & 0 & 0 & 0 & 222.7 \\
\hline Gas storage & 7.2 & 0 & 24.8 & 21.8 & 20.9 & 0 & 0 \\
\hline EV battery & 1.0 & 1.5 & 4.9 & 15.1 & 15.0 & 14.9 & 23.3 \\
\hline
\end{tabular}

621 In the DC sector, PTES storage was used and it stored heat at $95{ }^{\circ} \mathrm{C}$, before utilizing it in 622 absorption units. It was more efficient, more energy dense (lower space demand) and cheaper 623 solution than using cold (ice) storage which would store the cold generated in the absorption 624 units. Grid battery storage was only needed in the BAU scenario, where no DC was 625 implemented and in the Scenario 7 (non self-sufficient), in which the share of intermittent PV 626 generation reached $80 \%$ of the final electricity demand. The largest capacity of PTES storage 627 occurred in the Scenario 7, the one with the largest installed capacity of solar thermal.

628 Syngas (hydrogen) storage, together with SOFC and SOEC only occurred in the Scenario 7, 629 as it increased the flexibility in the energy system with large share of electricity demand met 630 by variable renewable energy generation.

631 Gas storage started to be feasible in scenarios that had significant share of installed PV 632 capacity, as in those scenarios gas CHP units needed to operate more flexibly, due to the 633 larger share of variable PV generation. In scenarios 6 and 7, gas storage was not feasible as 634 the gas demand was very low.

635 Finally, one can note that together with the electrification of the transport sector, there is an 636 important role of EV batteries, not only for the vehicles, but for the grid flexibility, too, as 637 vehicle-to-grid possibility was utilized in scenarios 4-7. The discharge of batteries to the 638 distribution grid amounted to $3.3 \%$ of the total EV batteries utilization in scenarios 4 and 5, $6391.1 \%$ in Scenario 6 and $15.5 \%$ in Scenario 7. The discharge of batteries to the grid in scenario $6401-3$ was $7.8 \%, 23.6 \%$ and $129.3 \%$ of the total electricity demand in the transport sector in 
those scenarios. Relatively large vehicle-to-grid utilization in the Scenario 3 was caused by

642 large share of PV variable generation and still not widely electrified transport sector (only

$64310 \%$ of transport sector was electrified in the Scenario 3).

644 Although the installed capacity of EV batteries in absolute terms in scenarios 1-3 was much 645 lower than in scenarios 4-7, its relative utilization was much larger.

646 It can be seen that the significant share of variable PV generation in Scenario 7 was absorbed 647 by the combination of increased size of thermal energy storage, demand side management of 648 industry and buildings, hydrogen technology (SOFC, SOEC and syngas storage), grid battery 649 storage and increased vehicle-to-grid utilization of EV batteries.

\section{Discussion}

652 The main goal of this paper was to assess whether district cooling adoption in hot and humid 653 climates would be socio-economically feasible at the system scale and whether it could serve 654 to integrate more intermittent renewable energy sources than in the business as usual case. 655 Another aim of the developed model was to find the optimal mix between the renewable 656 energy supply, district cooling and building energy efficiency. Both of the goals were 657 successfully achieved by integrating district cooling, along with other flexible technologies, 658 into the smart energy system. In all the scenarios (2-7) in which district cooling penetration 659 was between $37 \%$ and $98 \%$. The DC share was the largest in the Scenario 7, in which the 660 cheap thermal energy from solar thermal was unconstrained in capacity, as well as the 661 capacity of variable PV generation in the power sector. DC was important integration step as 662 it utilized heat available from waste, gas and biomass CHP units, geothermal and solar 663 thermal energy.

664 Comparing scenarios 2-7 with scenario 1 (BAU), one can note that significant PES savings 665 were achieved by the integration of DC. The reason was that DC was able to utilize waste 666 heat from gas and biomass CHP plants. Furthermore, a large capacity of the thermal energy 667 storage, which is cheaper than battery storage, was the reason why it was easier to integrate a 668 large share of variable renewables into the energy system. Having thermal energy storage in 669 the energy system allows for more subtle ramp ups and downs of CHP plants in the time when 670 PVs fulfil large share of electricity demand. Moreover, a large share of waste heat from waste 671 incineration plants, which cannot be operated in a flexible manner [45], was also successfully 672 integrated utilizing the DC system and thermal energy storage.

673 Other technologies that improved the flexibility of the energy system were reverse osmosis 674 (RO) technology, V2G possibility, SOFC and SOEC coupled with the syngas storage, as well 675 as load shifting possibilities (flexible demand) in industry and households. In the first three 676 scenarios, an overcapacity of RO technology ranged from $2.1 \%$ to $4.6 \%$. In the scenarios 4 to 6776 , the overcapacities were $9.5 \%, 8.1 \%$ and 5.8\%, respectively. In the Scenario 7, the RO 678 overcapacity was $0.1 \%$, as other flexibility sources proved to be more economically 679 beneficial. As RO technology consumes around $3.5 \mathrm{kWh}_{\mathrm{e}} / \mathrm{m}^{3}$ of desalinated water produced, 
resulting overcapacities introduced a significant flexibility in the energy system. When low marginal cost electricity was abundant, excess RO operation could consume more electricity, and correspondingly produce more desalinated water than needed in a specific hour. On the other hand, when marginal electricity price was expensive, RO could operate with lower capacity and consume already stored desalinated water.

SOEC and SOFC technologies (along with the syngas storage) were utilized in the Scenario 7, the scenario with the lowest overall socio-economic cost and the largest share of variable PV generation. The installed capacities of SOEC and SOFC were 1,826 and $434 \mathrm{MW}$, respectively. Both of those technologies introduced flexibility to the system as SOEC can be started when there is excess electricity supply in the system while SOFC can be utilized when there is a lack of power supply in the energy system. Although round trip electrical efficiency (power-to-gas-to-power) here was around 50\%, one part of the heat energy can be recovered from SOFC and used in absorption units for the DC system, increasing the overall energy efficiency of those technologies.

The $\mathrm{V} 2 \mathrm{G}$ possibility existed in all the scenarios, although large electrification of the transport sector occurred only in scenarios 4-6. In all the scenarios smart charge was anticipated, with the possibility of electric vehicles feeding the energy stored in their batteries back to the power grid when they were not utilized in the traffic. The most significant relative use of V2G possibility occurred in Scenario 3, the one with the large capacity of variable renewable energy generation and relatively small share of electrified transport. V2G use was also very frequent in the Scenario 7, the one in which both variable renewable energy generation and electrified transport reached very high levels.

Load shifting was utilized in scenarios 5,6 and 7, the only scenarios where the load shifting was allowed. The load shifting in industry was utilized at $9 \%$ and $6 \%$ and $11 \%$ of the maximum potential in scenarios 5-7, respectively. In the households sector, it was utilized $5 \%, 3 \%$ and $6 \%$ in scenarios 5-7, respectively. However, it is very interesting to note that the load shifting in the case study in this paper actually increased the peak electricity demand. However, those peak demands correlated with the peak PV generation, meaning that the marginal costs of electricity production were still lower than in the case without utilizing the load shifting possibility. On the other hand, it is important to note that the congestion in distribution grid was not modelled here, which could curb the possibility to increase peak electricity demand even more.

One can also note from the different storage capacities that the smart energy system seeks for integration of different storage types and there is not a winner-takes-it-all solution. However, it is indeed interesting to note that the optimal size of the PTES thermal energy storage was much larger than the battery storage in all the scenarios, except the BAU scenario that had no DC at all. Other important finding is that the optimal battery storage capacity of electric vehicles was much larger than the grid battery storage, in scenarios where the electrification of the transport sector occurred.

The air pollution, measured in terms of NOx, SOx and PM emissions, was much lower in scenarios 2-5 (except SOx emission in scenario 3) compared to the BAU scenario. The latter 
was the consequence of significantly lower gas consumption due to increased energy efficiency within the system, as well as due to the electrification of the transport sector. However, in Scenario 6, in which $\mathrm{CO}_{2} \mathrm{e}$ emissions were significantly constrained, biomass demand significantly increased. The latter caused a much larger air pollution than in the Scenario 4, showing that the sole focus on $\mathrm{CO}_{2} \mathrm{e}$ emissions can worsen the air pollution issue. In Scenario 7, the large share of PV and solar thermal technologies resulted in much lower biomass demand than in the Scenario 6, significantly reducing the air pollution emissions. When discussing about the internalization of the negative health externalities, one should note that the air pollution costs were approximately 26 times larger in scenarios 1-3 than the mean of air pollution costs in scenarios 4-7. The latter shows that the non-point sources of air pollution, such as gasoline driven vehicles, have much larger negative externalities compared to the point source polluting generators.

Two different sensitivity analyses were carried out; the one on internalization of air pollution costs and the other on the consequences of the exclusion of import/export power capacity. As presented in Table 2, three different air pollution cost levels were calculated from the presented literature. As the middle cost rate was used in this paper, the sensitivity analysis was carried out by adopting low and high cost levels in Scenario 6. Implementing low and high air pollution cost levels did not have significant influence on the optimal technology mix in the energy system. However, it did have the influence on the total socio-economic costs of the energy system. Assuming low and high air pollution cost levels resulted in a total air pollution cost of 29 million $€$ and 95 million $€$, respectively, compared to the 63 million $€$ when middle cost rate was adopted. The latter resulted in a total socio-economic cost difference of energy system of $\pm 1 \%$, when using low and high air pollution cost levels. Thus, although adopting different air pollution cost levels can have significant influence on the total air pollution costs itself, the resulting difference in the total socio-economic costs of the energy system is much less pronounced.

Allowing import/export of electricity over the city borders was the other sensitivity analysis that was carried out. Up to 1,650 MW of transmission capacity over the system boundaries was allowed in the system, following the potential future development of the ASEAN power grid [55]. The sensitivity analysis showed that the maximum possible transmission capacity would be invested in. Based on the runs for the Scenario 5, the total socio-economic costs would be lower $0.1 \%$, capital costs would reduce for $0.6 \%$ while the total operating costs would increase for $0.4 \%$. The analysis of the technology portfolio revealed that the import/export transmission capacity halved the needed capacity for the large-scale gas storage. It had further caused a significant decrease in the overcapacity of the reversible osmosis. The latter shows that the four flexibility possibilities presented in this paper can mutually compete and one must carefully optimize the energy system in order to avoid inefficiencies and suboptimal solutions. Capacities of other technologies changed only marginally compared to the original Scenario 5.

760 Hourly operation of five different large scale storages (Appendix A) showed that none of the 761 storages was utilized in a steady, intra-day pattern. The latter shows that one should be 762 especially careful when decomposing the model using typical days, weeks or time slices in 
general. Case study developed in this paper shows that using typical time slices cannot realistically model different storages in an optimal way, as they do not have regular charging and discharging patterns in a complex system like the one modelled in this paper. The latter finding can be observed by following the hourly patterns of storage charging and discharging, presented in the Appendix A.

Predefined technologies that were not economically feasible in the modelled energy system were, wind energy, waste heat from data centres coupled with heat pumps and natural gas and methanol synthesis from syngas.

Wind energy does not have suitable locations in Singapore in terms of wind speed, while waste heat from data centres coupled with heat pumps were prohibitively expensive considering the need for raising the very low temperature level of the waste heat $\left(40{ }^{\circ} \mathrm{C}\right)$ to 95 ${ }^{\circ} \mathrm{C}$ and then utilizing it in absorption chillers with COP value of 0.7. Both natural gas and methanol synthesis options were not feasible enough (also including losses during syngas production and the final energy conversions of either synthetic natural gas or methanol) to be utilized in the system, compared to other available technologies such as electrified transport and biomass CHPs coupled with sea algae production.

In comparison with other studies that can be found in the literature, scenarios 2-5 showed similar DC penetration levels as the one anticipated for Dubai. In Dubai, with air conditioning responsible for $70 \%$ of final electricity demand, the city aims to meet 40 per cent of its cooling needs through district cooling by 2030 [56]. In [57], it has been emphasized that the DC should first and foremost utilize natural cooling of rivers or sea, as well as the heat available from nature, such as geothermal energy. The former was not possible to be utilized in Singapore, due to the lack of any significant temperature difference of the air, ground or sea [7], while the latter was confirmed in the case of Singapore, as the maximum potential of geothermal energy was utilized in scenarios 2-7. As shown in the literature, smart energy systems were not researched in the tropical climate so far. However, they have been well researched for the colder regions. In [58], for the smart energy system in 2050, 50\% of heat demand has been met by district heating, most of the transport sector has been electrified and energy efficiency of buildings has increased by $50 \%$. Scenarios 2-5 from this paper showed similar district energy penetration levels, while energy efficiency in buildings reduced the cooling demand for $22.3 \%$ in scenarios 5-7. Majority of the transport sector in the city of Singapore was electrified, up to $98 \%$ in scenarios $4-7$.

The author in [59] showed for the case of Denmark, that a smart energy system with $80 \%$ of electricity generated from renewable energy sources, PV should correspond to the $20 \%$ of the renewable electricity generated. In the scenario 7 from this paper, when PV capacity was not constrained by the space availability, $80 \%$ of the final electricity demand was met by variable PV generation. The latter points to the significant difference between modelling smart energy systems in tropical regions and smart energy systems in regions with colder climates, which have emphasized seasonality. The steady solar irradiation and the lack of seasonality, as well as steady cooling demand throughout the year, fosters much larger shares of variable PV generation compared to the colder climates. 
804 The authors in [22] focused on the optimal mix between energy savings and district heat 805 supply. They showed for the case of four different European countries that the thermal energy 806 savings in buildings should account for 0-60\%, mainly based on the price of the available heat 807 supply. In the case of Singapore from this paper, the heat savings in buildings accounted for $80822.3 \%$. The latter result is in line with [22], as Singapore had lots of heat available from CHP 809 plants, geothermal and solar thermal energy, which made it cheaper to generate more cold 810 than to invest large amount of funds for very large energy efficiency improvement in the 811 buildings sector.

812 For the future case and the model development from the perspective of cities, it would be 813 beneficial to integrate the industrial sector in the modelling of air pollution. Considering 814 different case studies, better representations of energy efficiency options, technologies such as 815 pumped hydro, concentrated solar power, wind and others could prove to be feasible. 816 Moreover, integrating a smart water system into the model and optimizing pumping power, 817 especially in a flat land like Singapore could further lead to increased efficiency of the whole 818 energy system. Further focusing on the outlook of this study, it is important to mention that 819 the expected population growth until the year 2050 will be highly uneven [60]. Almost all the 820 population increase will occur in the Middle East, Latin America and Africa, majority of 821 which will happen in the tropical region [60]. Hence, this case study is widely applicable to 822 the other cities in the tropical region, in which population growth and economic development will significantly increase energy demand for cooling, transportation and other services. Thus, this paper will hopefully contribute to the discussion on potential of avoiding long term lockin effects in the energy decisions that will significantly curb the potential for carbon and air pollution emissions control.

\section{Conclusions}

The research carried out in this paper showed that the integration of different energy sectors in the tropics can significantly reduce the socio-economic costs of urban energy systems, and at the same time provide cleaner air and mitigation of carbon emissions. The optimal smart urban energy system of Singapore included a certain share of district cooling, demand side management in industry and households, as well as in the water sector (reversible osmosis),

834 energy efficiency measures in buildings, different storage technologies and renewable energy 835 supply.

836 All the scenarios representing stepwise integration of the energy sectors showed significant 837 socio-economic cost savings, reduction in $\mathrm{CO}_{2} \mathrm{e}$ emissions and lower primary energy supply. 838 In socio-economic terms, the best performing scenario (Scenario 5) resulted in $49 \%$ lower $839 \mathrm{CO}_{2} \mathrm{e}$ emissions, 7\% lower primary energy supply and 55\% savings in the total socio840 economic costs. The best performing scenario in terms of $\mathrm{CO}_{2} \mathrm{e}$ emissions (Scenario 6) 841 showed $46 \%$ lower socio-economic costs, $68 \%$ reduction in $\mathrm{CO}_{2} \mathrm{e}$ emissions and $5 \%$ reduction 842 in primary energy supply. 
Air pollution was also reduced in all the alternative scenarios. However, in the scenario with the lowest $\mathrm{CO}_{2} \mathrm{e}$ emissions (Scenario 6), air pollution was significantly larger than in the Scenarios 4 and 5, due to the increased use of biomass, which was modelled as $\mathrm{CO}_{2} \mathrm{e}$ neutral technology in the energy system (all the biomass demand needed to be met by sea algae production).

A comparison between the cases when the energy system of the city seeks for achieving the self-sustainability and when it also utilizes the energy from its surroundings (Scenarios 6 and 7) showed that achieving the same $\mathrm{CO}_{2} \mathrm{e}$ levels is cheaper by utilizing the energy from the city surroundings, too.

Future research on urban energy systems could further integrate water distribution system, including the needed pumping power for the water distribution, include job creation potential of different technologies, as well as behavioural economics of the demand side of the energy system, to capture non-optimal decisions of the humans better.

\section{Acknowledgments}

This work was financed as a part of the CITIES project $n^{\circ}$ DSF1305-00027B funded by the Danish Innovationsfond. Its contribution is greatly acknowledged.

\section{References}

[1] International Energy Agency. Energy and Climate Change. 2015. doi:10.1038/479267b.

[2] COP21. COP21 2015. http://www.cop21 paris.org/about/cop21 (accessed May 8, 2017).

[3] United Nations. World Urbanization Prospects. 2014.

[4] International Renewable Energy Agency. Renewable energy in cities. Abu Dhabi: 2016.

[5] International Energy Agency. Energy and Air Pollution. 2016.

[6] World Health Organization. Air pollution levels rising in many of the world's poorest cities 2016. http://www.who.int/mediacentre/news/releases/2016/air-pollution-rising/en/ (accessed May 8, 2017).

[7] Bruelisauer M, Meggers F, Leibundgut H. Choosing heat sinks for cooling in tropical climates. Front Archit Res 2013;2:292-300. doi:10.1016/j.foar.2013.05.004.

[8] An J, Yan D, Hong T, Sun K. A novel stochastic modeling method to simulate cooling loads in residential districts. Appl Energy 2017;206:134-49. doi:10.1016/j.apenergy.2017.08.038.

[9] del Hoyo Arce I, Herrero López S, López Perez S, Rämä M, Klobut K, Febres JA. Models for fast modelling of district heating and cooling networks. Renew Sustain Energy Rev 2017:1-11. doi:10.1016/j.rser.2017.06.109.

[10] Oppelt T, Urbaneck T, Gross U, Platzer B. Dynamic thermo-hydraulic model of district cooling networks. Appl Therm Eng 2016;102:336-45. doi:10.1016/j.applthermaleng.2016.03.168.

[11] Ang BW, Wang H, Ma X. Climatic influence on electricity consumption: The case of Singapore and Hong Kong. Energy 2017;127:534-43. doi:10.1016/j.energy.2017.04.005.

[12] Werner S. International review of district heating and cooling. Energy 2017:1-15. doi:10.1016/j.energy.2017.04.045.

[13] Kang J, Wang S, Gang W. Performance of distributed energy systems in buildings in cooling dominated regions and the impacts of energy policies. Appl Therm Eng 2017;127:281-91. doi:10.1016/j.applthermaleng.2017.08.062.

[14] Hughes BR, Rezazadeh F, Chaudhry HN. Economic viability of incorporating multi-effect 
distillation with district cooling systems in the United Arab Emirates. Sustain Cities Soc 2013;7:37-43. doi:10.1016/j.scs.2012.10.002.

[15] Kılkış B. Exergetic comparison of wind energy storage with ice making cycle versus minihydrogen economy cycle in off-grid district cooling. Int J Hydrogen Energy 2017;42:1757182. doi:10.1016/j.ijhydene.2017.03.105.

[16] Milligan M, Frew B, Zhou E, Arent DJ. Advancing System Flexibility for High Penetration Renewable Integration 2015. doi:10.2172/1225920.

[17] Kessels K, Claessens B, D'Hulst R, Six D. The value of residential flexibility to manage a BRP portfolio: A Belgian case study. 2016 IEEE Int Energy Conf ENERGYCON 20162016. doi:10.1109/ENERGYCON.2016.7513890.

[18] Klobasa M. Dynamische Simulation eines Lastmanagements und Integration von Windenergie in ein Elektrizitätsnetz. 2007. doi:10.3929/ethz-a-005484330.

[19] De Luca G, Fabozzi S, Massarotti N, Vanoli L. A renewable energy system for a nearly zero greenhouse city: Case study of a small city in southern Italy. Energy 2018. doi:10.1016/j.energy.2017.07.004.

[20] Dong C, Huang GH, Cai YP, Liu Y. An inexact optimization modeling approach for supporting energy systems planning and air pollution mitigation in Beijing city. Energy 2012. doi:10.1016/j.energy.2011.10.030.

[21] Zvingilaite E. Human health-related externalities in energy system modelling the case of the Danish heat and power sector. Appl Energy 2011;88:535-44. doi:10.1016/j.apenergy.2010.08.007.

[22] Hansen K, Connolly D, Lund H, Drysdale D, Thellufsen JZ. Heat Roadmap Europe: Identifying the balance between saving heat and supplying heat. Energy 2016;115:1663-71. doi:10.1016/j.energy.2016.06.033.

[23] Lund H, Østergaard PA, Connolly D, Mathiesen BV. Smart energy and smart energy systems. Energy 2017;137:556-65. doi:10.1016/j.energy.2017.05.123.

[24] Dominković DF, Bačeković I, Sveinbjörnsson D, Pedersen AS, Krajačić G. On the way towards smart energy supply in cities: The impact of interconnecting geographically distributed district heating grids on the energy system. Energy 2017;137:941-60. doi:10.1016/j.energy.2017.02.162.

[25] Dominković DF, Pedersen AS, Elmegaard B. A multi-objective energy planning including system exergy eciency and socio-economic costs. Proc. 30th Int. ECOS Conf. San Diego, USA, July 2017, 2017.

[26] P. Bickel, F. Rainer,. ExternE: Externalities of Energy: methodology 2005 Update. 2005.

[27] Lott MC, Pye S, Dodds PE. Quantifying the co-impacts of energy sector decarbonisation on outdoor air pollution in the United Kingdom. Energy Policy 2017;101:42-51. doi:10.1016/j.enpol.2016.11.028.

[28] The World Bank Data n.d. https://data.worldbank.org/indicator/NY.GNP.PCAP.PP.CD.

[29] Quah E, Boon TL. The economic cost of particulate air pollution on health in Singapore. J Asian Econ 2003;14:73-90. doi:10.1016/S1049-0078(02)00240-3.

[30] Dominković DF, Bin Abdul Rashid KA, Romagnoli A, Pedersen AS, Leong KC, Krajačić G, et al. Potential of district cooling in hot and humid climates. Appl Energy 2017;208:49-61. doi:10.1016/j.apenergy.2017.09.052.

[31] Dominković DF, Romagnoli A, Fox T, Schrøder Pedersen A. Potential of waste heat and waste cold energy recovery in Singapore for district cooling applications: impacts on energy system. 40th IAEE Int. Conf. - Singapore, 2017.

[32] Bloomberg, Murtaugh D. CO2 tax 2017. https://www.bloomberg.com/news/articles/2017-0220/singapore-plans-southeast-asia-s-first-carbon-tax-by-2019 (accessed March 11, 2017).

[33] European Comission. EU Reference Scenario 2016 Energy, transport and GHG emissions Trends to 2050 Main results 2016. doi:10.2833/9127.

[34] Danish Energy Agency. Forudsætninger for samfundsøkonomiske analyser på energiområdet. 2016.

[35] Energinet.dk; Danish Energy Agency. Technology data for energy plants. 2012.

[36] Hooftman N, Oliveira L, Messagie M, Coosemans T, Van Mierlo J. Environmental analysis of petrol, diesel and electric passenger cars in a Belgian urban setting. Energies 2016;9:1-24. 
doi:10.3390/en9020084.

[37] European Environment Agency. Emission Inventory Guidebook: Road transport. 1999.

[38] Johansson B, Åhman M. A comparison of technologies for carbon-neutral passenger transport. Transp Res Part D Transp Environ 2002;7:175-96. doi:10.1016/S1361-9209(01)00018-9.

[39] Buekers J, Van Holderbeke M, Bierkens J, Int Panis L. Health and environmental benefits related to electric vehicle introduction in EU countries. Transp Res Part D Transp Environ 2014;33:26-38. doi:10.1016/j.trd.2014.09.002.

[40] Cormio C, Dicorato M, Minoia A, Trovato M. A regional energy planning methodology including renewable energy sources and environmental constraints. Renew Sustain Energy Rev 2003. doi:10.1016/S1364-0321(03)00004-2.

[41] The Oxford Institute for Energy Studies, Robinson D, Keay M, Hammes K. Fiscal policy for decarbonisation of energy in Europe. 2017.

[42] Energinet.dk. Technology data for energy plants. 2012. doi:ISBN: 978-87-7844-940-5.

[43] Caldera U, Breyer C. Learning Curve for Seawater Reverse Osmosis Desalination Plants: Capital Cost Trend of the Past, Present, and Future. Water Resour Res 2017:523-38. doi:10.1002/2017WR021402.

[44] Deng J, Wang RZ, Han GY. A review of thermally activated cooling technologies for combined cooling, heating and power systems. Prog Energy Combust Sci 2011;37:172-203. doi:10.1016/j.pecs.2010.05.003.

[45] Tomić T, Dominković DF, Pfeifer A, Schneider DR, Pedersen AS, Duić N. Waste to energy plant operation under the influence of market and legislation conditioned changes. Energy 2017;137:1119-29. doi:10.1016/j.energy.2017.04.080.

[46] Mathiesen BV, Lund H, Karlsson K. 100\% Renewable energy systems, climate mitigation and economic growth. Appl Energy 2011;88:488-501. doi:10.1016/j.apenergy.2010.03.001.

[47] ClimateWorks Australia - Australian Government, Department of Industry,. Industrial demand side response potential. 2014.

[48] COWI Consortium - DG Energy European Comission. Impact assessment study on downstream flexibility, price flexibility, demand response and smart metering. 2016.

[49] Building and Construction Authority. Building Energy Efficiency R\&D Roadmap. 2013.

[50] Luther J, Reindl T. Solar Photovoltaic (PV) Roadmap for Singapore. 2013.

[51] Oliver GJH, Palmer AC, Tjiawi H, Zulkefli F. Engineered geothermal power systems for Singapore. IES J Part A Civ Struct Eng 2011;4:245-53. doi:http://dx.doi.org/10.1080/19373260.2011.598261.

[52] Singapore's National Water Agency (PUB). Our Water, Our Future. 2016.

[53] EDB Singapore, NEA Singapore. INDUSTRY ENERGY EFFICIENCY Technology Roadmap. 2015.

[54] Dominković DF, Bačeković I, Pedersen AS, Krajačić G. The future of transportation in sustainable energy systems: Opportunities and barriers in a clean energy transition. Renew Sustain Energy Rev 2018;82:1823-38. doi:10.1016/j.rser.2017.06.117.

[55] ASEAN Centre for Energy. Our Journey in 2017. n.d.

[56] UNEP (United Nations Environment Programme). District Energy in Cities: Unlocking the Potential of Energy Efficiency and Renewable Energy. 2015.

[57] Butters C, Nordin A, Khai DTH. District Cooling: A Key Solution for Hot Climate Cities. In: Cheshmehzangi A, Butters C, editors. Des. Cool. Cities Energy, Cool. Urban Form Asian Perspect., Singapore: Springer Singapore; 2018, p. 151-71. doi:10.1007/978-981-10-66382_11.

[58] Dominković DF, Bačeković I, Ćosić B, Krajačić G, Pukšec T, Duić N, et al. Zero carbon energy system of South East Europe in 2050. Appl Energy 2016. doi:http://dx.doi.org/10.1016/j.apenergy.2016.03.046.

[59] Lund H. Large-scale integration of optimal combinations of PV, wind and wave power into the electricity supply. Renew Energy 2006;31:503-15. doi:10.1016/j.renene.2005.04.008.

[60] United Nations Department of Economic and Social Affairs. World Population Prospects The 2017 Revision Key Findings and Advance Tables. 2017. doi:10.1017/CBO9781107415324.004. 
997




998

999

1000

1001

1002

1003

1004

1005

1006

1007

1008 Electric vehicles batteries storage level (Scenario 7):

\section{Appendix A}

Hourly operation of different storages.

Pit thermal energy storage (PTES) level (Scenario 7):

Grid electric battery storage level (Scenario 7):
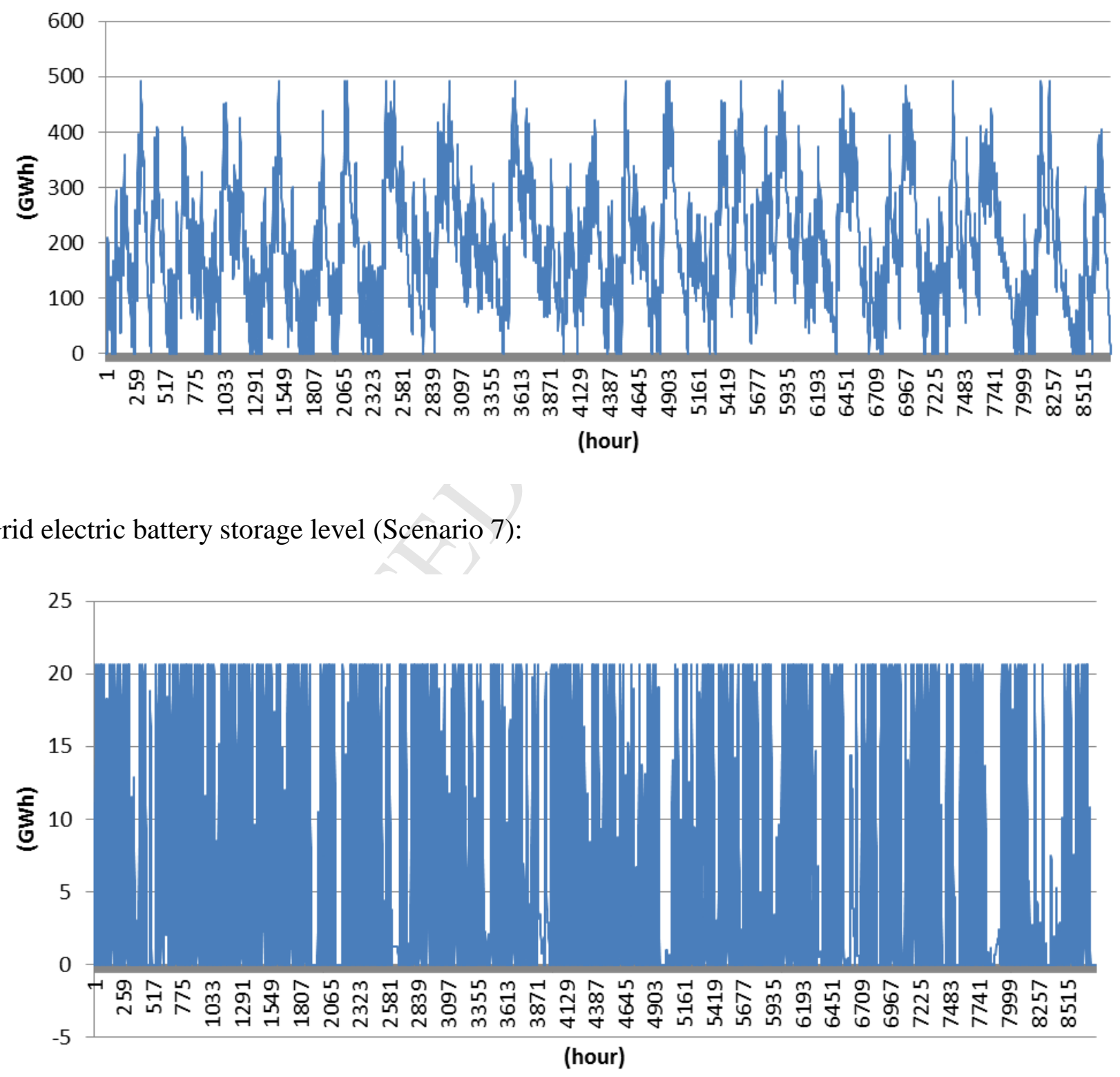


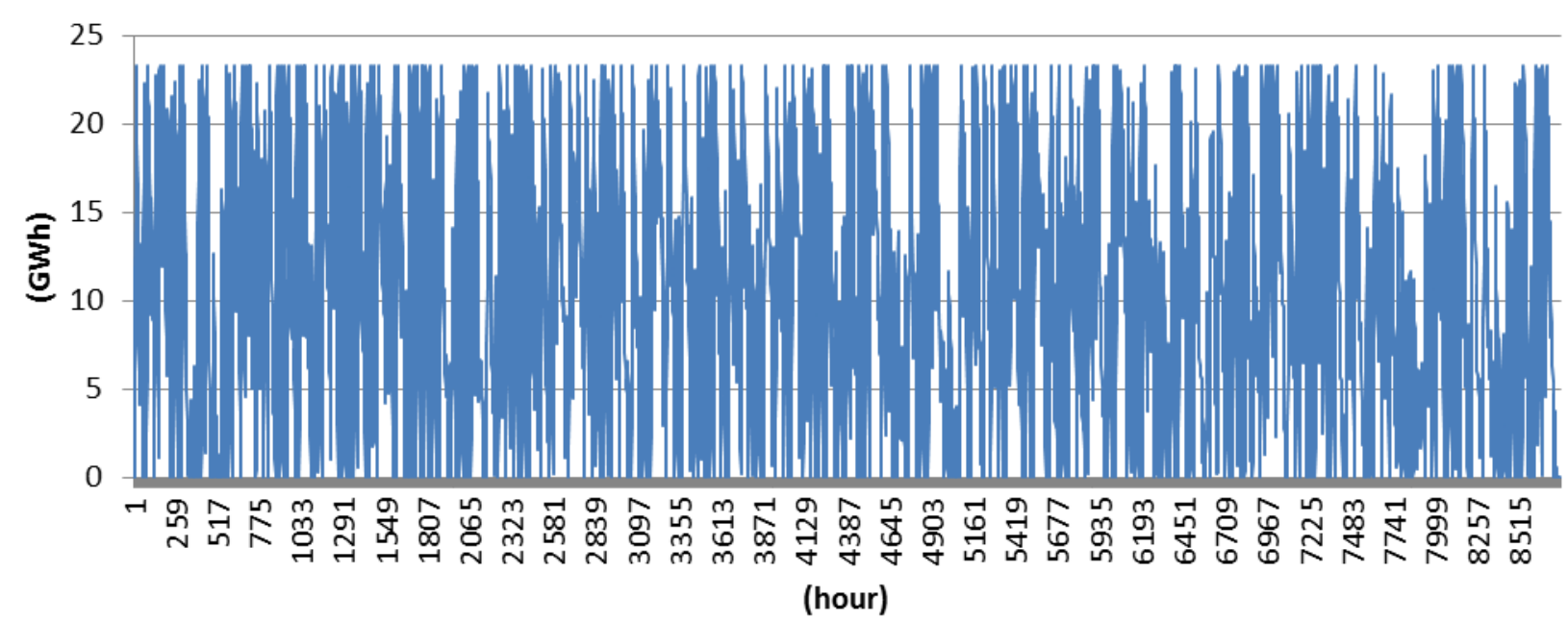

1009

1010

1011 Syngas storage level (Scenario 7):

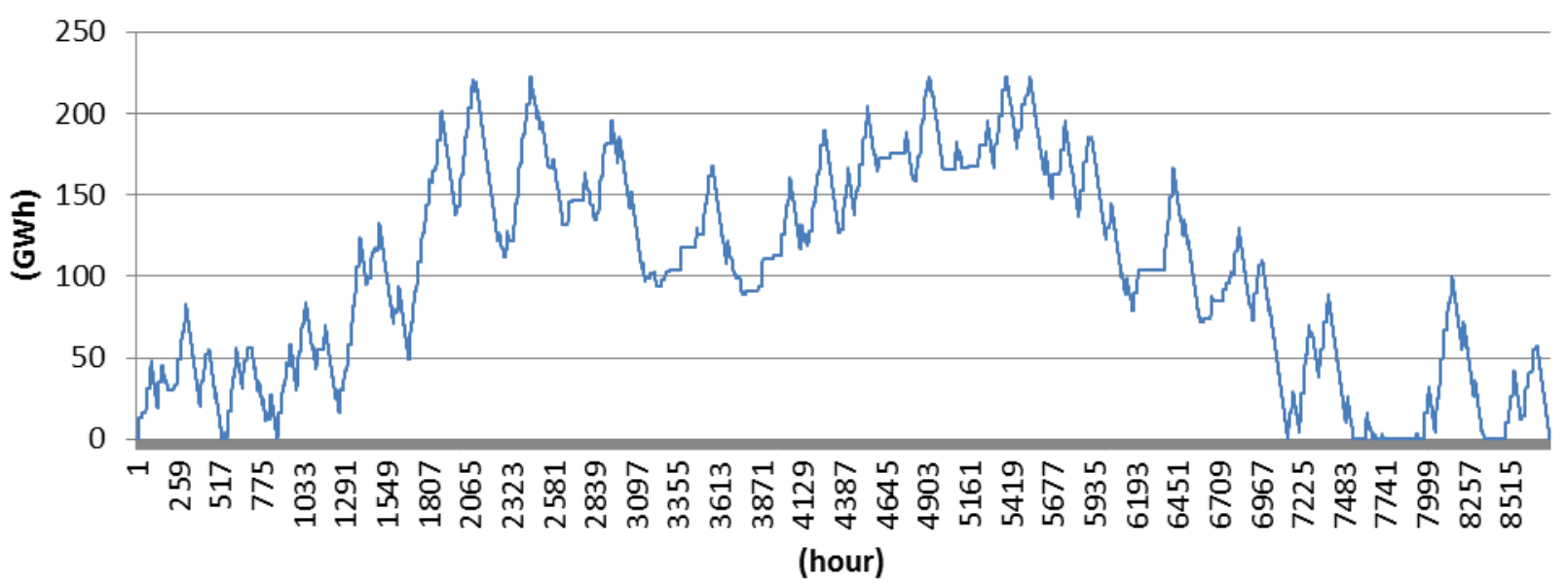

1012

1013

1014 Gas storage level (Scenario 5):

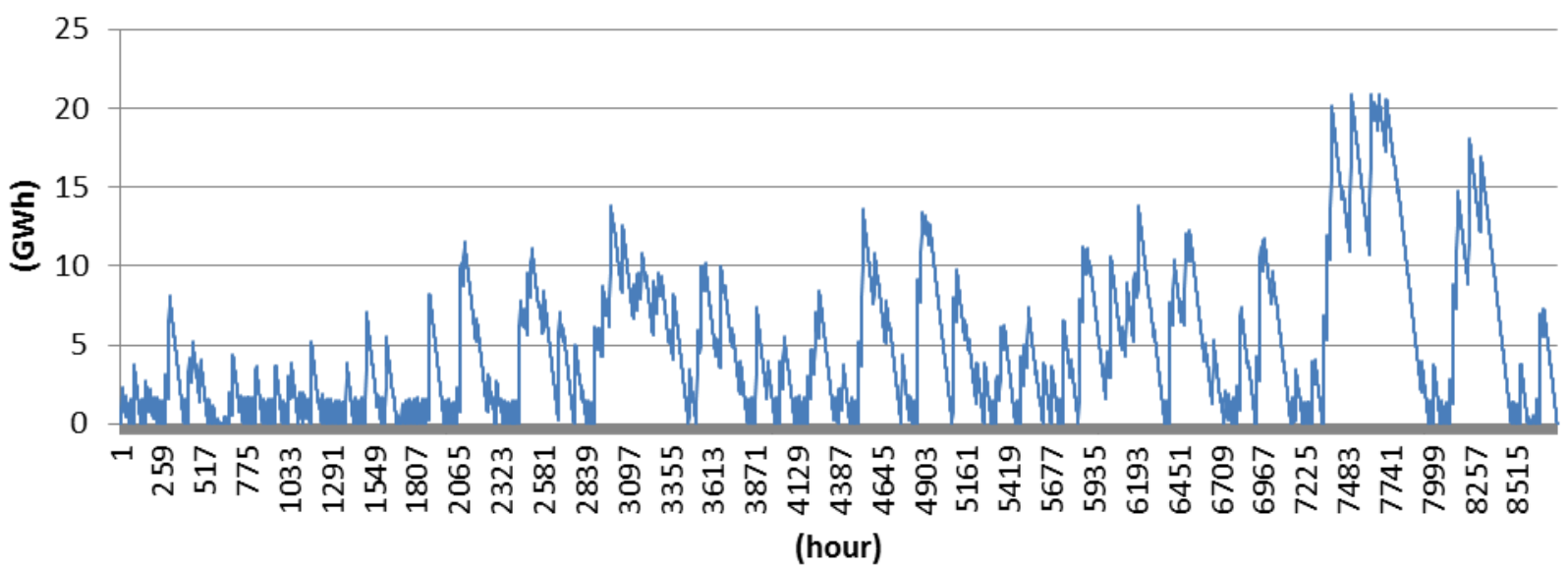


1016

1017

1018

1019

1020 Where levelized investment costs were calculated using Eq. (B.2).

1021

1022

1023

1024

1025

1026

1027

1028

1029

1030

1031

1032 Individual cooling energy balance:

1033 chiller $_{\text {individual }} \geq$ ind_cool $_{\text {demand }}$

1034 The share between the individual and district cooling demand:

$1035 D C_{\text {demand }}+$ ind_cool demand $\geq \operatorname{cool}_{\text {demand,total }}-\operatorname{cool}_{\text {en,ef }}$

1036 Absorption chillers energy balance: geothermal $_{D C}-R O-\frac{\text { SOEC }}{\eta_{S O E C}}+f l e x-$ flex $_{C h} \geq e l_{-}$dem

Gas demand sector: gas_dem

District cooling energy generation balance: $D C_{\text {demand }}$

$$
\text { lev_inv } v_{i}=\operatorname{inv}_{i} \cdot \frac{\text { dis_rate }_{i}}{1-\left(1+\text { dis_rate }_{i}\right)^{- \text {lifetims }_{i}}}
$$

\section{$\underline{\text { Inequality constraints }}$}

Power sector balance:

$x_{j, E L, g a s}+x_{j, E L, \text { biomass }}+x_{j, E L, \text { other }}+x_{j, \text { battery,storage_grid_dis }}+x_{j, \text { grid_battery,storage_dis }}+$ SOFC $-x_{j, \text { battery, storage }}-x_{j, \text { grid }}$ battery, storage $_{c h}-\frac{\text { chiller }_{D C}}{\operatorname{COP}_{D C_{c h i l l e r}}}-\frac{\text { chiller }_{\text {individual }}}{\operatorname{COP}_{\text {individual }}}-0.1$.

$x_{j, a n_{-} \text {dig }}+$ gas_imp $_{-}+$gas $_{\text {synthesis }}+x_{j, g a s_{\text {storage }}}-x_{j, g a s, \text { storage_ch }}-\frac{x_{j, E L, g a s}}{\eta_{j}} \geq$

$a b s_{D C}+$ geothermal $_{D C}+$ chiller $_{D C}+x_{j, \text { cold,storage_grid_dis }}-x_{j, \text { cold }_{\text {storage }} \text { grid }_{c h}} \geq$ 
$x_{j, \text { wasteheat }, l} \geq\left(a b s_{D C} / C O P_{a b s}\right)$

1038 Transport demand energy balance:

1039 petr $_{\text {dem }}+$ ele $e_{\text {transport }} \cdot C_{1}+$ methanol $\geq$ transp_demand

1040 Syngas (hydrogen) balance:

1041 SOEC $-\frac{\text { SOFC }}{\eta_{\text {SOFC }}}-\frac{\text { gas }_{\text {synthesis }}}{\eta_{\text {SNG }}}-\frac{\text { methanol }}{\eta_{m}}+x_{j, \text { syngas,storagedis }}-x_{j, \text { syngas,storag } e_{c h}} \geq 0$

1042 Gasoline energy balance:

1043 petr $_{\text {imp }} \geq$ petr $_{\text {dem }}$

1044 Desalinated water production balance:

$1045 R O \geq$ water $_{\text {demand }}$

1046 Capacity of technologies constraints:

$1047 x_{j} \leq x_{i} \cdot t$

$1048 \quad x_{k} \leq x_{i} \cdot t$

1049 Environmental constraints:

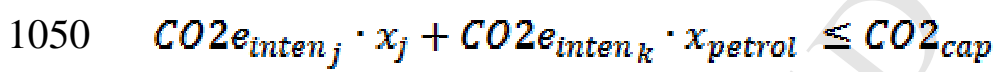

$1051 \frac{x_{j, E L, b i o m a s s}}{\eta_{j, E L}} \leq$ algae_prod

1052 Equality constraints

1053 Electric vehicle battery storage energy balance:

1054

1055

battery_level $_{r}=$ battery_level $_{r-1}+x_{j, \text { battery,storage }{ }_{-} \text {ch, } r}-x_{j, \text { battery,storage }}$ dis,$_{r}$,

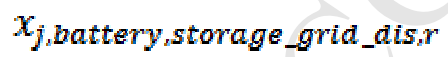

1056 Heat storage balance equation*:

heat_level $l_{r}=$ heat_level $_{r-1}+x_{j, \text { heat,storage_ch, } r}-x_{j, \text { heat,storage_dis, } r}$

1057 Starting-end point storage constraint:

1058 heat_level ${ }_{1}=$ heat_level $l_{8760}=0$

1059 *Syngas (hydrogen) storage, natural gas storage and battery grid storage were modelled in 1060 the same manner as the heat storage. 
1061 Energy balance for flexible demand in industry and buildings (shifted energy demand)

1062 flex $=$ flex $_{\text {ch }}$

1063 Building energy efficiency scenario (constraining that only one energy efficiency scenario can 1064 be chosen, as they are mutually exclusive):

$1065 \sum_{l=1}^{y} B_{y}=1$ 
- integrated model for smart urban energy system was developed

- air pollution in cities was modelled as a part of the holistic energy system model

- five large scale energy storage types were modelled

- optimal share of district energy, energy efficiency and renewable supply was found

- the economic impact of seeking for energy self-sufficiency of cities was calculated 